ANDREW HYNES SERIES: TECTONIC PROCESSES

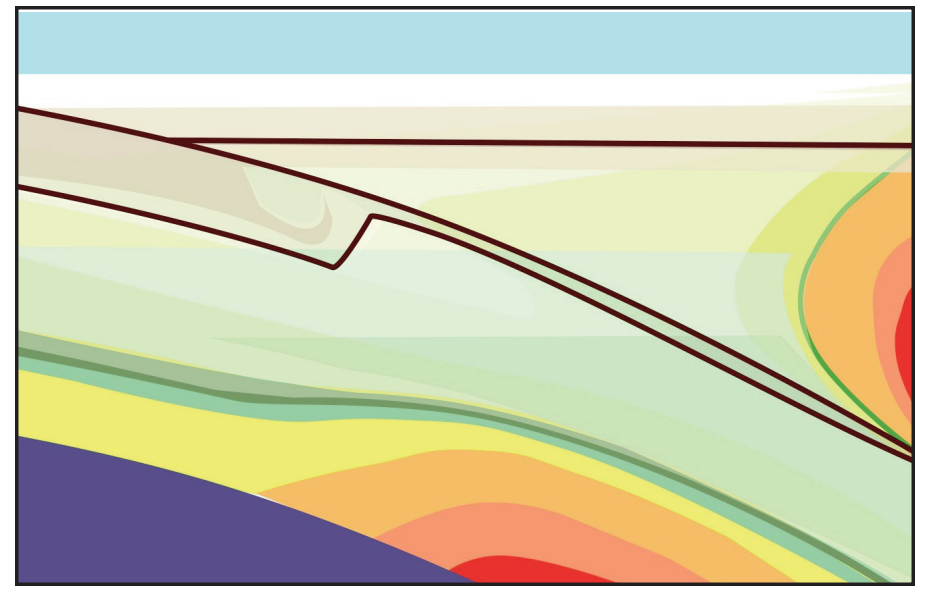

\section{Tectonic Consequences of a Uniformly Hot Backarc and Why is the Cordilleran Mountain Belt High?}

\author{
R.D. Hyndman \\ Pacific Geoscience Centre, Geological Survey of Canada and \\ School of Earth and Ocean Sciences \\ University of Victoria \\ 9860 W. Saanich Road, Sidney \\ British Columbia, V8L 4B2, Canada \\ Email:rbyndman@nrcan.gc.ca
}

\section{SUMMARY}

Why is the North American Cordilleran mountain belt high? We expect a thick crust to support high elevations by isostasy but, remarkably, the Cordilleran crust is thin. There is no crustal root. An important recent recognition is that the high elevation is supported by thermal expansion rather than by thickened crust. The elevation of the Cordillera is only one consequence of the Cordillera being uniformly hot and having a thin lithosphere, in common with most current or recent backarcs. Some other consequences of the high temperatures compared to the adjacent cool craton include: (1) The Cordillera and other backarcs are hot, weak mobile belts that can be deformed by available plate-tectonic forces, in contrast to stable cratons that cannot; (2) Most continental seismicity is concentrated in backarcs; (3) In the Cordillera there is widespread sporadic 'backarc' volcanism; (4) The high temperatures result in very low strength in the lower crust that allows lower-crust detachment; (5) The lower crust weakness facilitates large-scale crustal oroclines that may be independent of the upper mantle; (6) The lower crust in the Cordillera and other backarcs is in amphibolite- to granulite-facies conditions, $\sim 800-900^{\circ} \mathrm{C}$ at the Moho; (7) In ancient backarcs globally, regional Barrovian metamorphism is concluded to be the result of high temperatures that predate the orogenic collision and deformation. No "heat of orogeny" is required. Following the termination of subduction, backarcs cool with a time constant of 300-500 m.y.

\section{RÉSUMÉ}

Pourquoi la chaîne de montagnes de la Cordillère nord-américaine est-elle si haute? On comprend qu'une croûte sur-épaisse puisse expliquer une grande élévation, mais voilà, la croûte de la Cordillère est mince. Il n'existe pas de racine crustale. Or, récemment, une conclusion importante s'est imposée, soit que cette haute élévation s'explique par l'expansion thermique plutôt que par l'existence d'une croûte sur-épaisse. L'élévation de la Cordillère n'est qu'une des conséquences d'une Cordillère uniformément chaude flottant sur une lithosphère mince, caractéristiques communes aux zones d'arrière-arc actuelles ou récentes. Quelques unes des autres conséquences de cette haute température, par opposition aux froids cratons adjacents, comprennent: (1) La Cordillère et d'autres zones d'arrièresarcs sont des zones chaudes et facilement déformables par les forces tectoniques ambiantes, contrairement aux cratons stables; (2) La majorité de l'activité sismique continentale est concentrée dans le zones d'arrière-arc; (3) Dans la Cordillère l'activité volcanique sporadique est généralisé; (4) Ces températures élevées explique la très faible rigidité de la croûte inférieure et les décollements qu'elle subit; (5) La flaccidité de la croûte inférieure facilite la formation d'oroclinaux de grandes magnitudes qui peuvent être indépendants du manteau supérieur; (6) La croûte inférieure de la Cordillère et d'autres zones d'arrière-arc sont dans la zone de faciès amphibolite à granulite, soit 800 à 900oC à la discontinuité Moho; (7) Globalement dans les anciennes zones d'arrière-arc, le métamorphisme régional barrovien s'explique alors comme étant le résultat des hautes températures antérieures à la collision et à la déformation orogénique. Aucune "chaleur orogénique » n’est nécessaire. Après la période de subduction, les zones d'ar- 
rière-arc se refroidissent à l'intérieur d'un intervalle de temps de 300 à 500 millions d'années.

\section{Traduit par le Traducteur}

\section{INTRODUCTION}

In the past few years there have been important developments in our understanding of the processes that control the large-scale tectonics of the Cordillera and other continental subduction zone backarcs, and also their ancient analogues, mainly based on geophysical data. My aim in this article is to communicate this new tentative understanding to the geological community, and to encourage the regional geological studies, analyses and interpretations that are needed to test our conclusions.

As I discuss later in more detail, I define 'backarc' thermally, as the welldefined region of uniformly high crustal and upper-mantle temperatures now recognized landward of continental-arc volcanic chains, but backarcs generally also correspond to tectonic 'mobile belts' and to high-elevation 'mountain belts.' In the geological record, we interpret the main parts of most 'orogenic belts' as ancient backarcs. For the Cordillera, the backarc hinterland defined this way extends from the Cascadia volcanic arc (and recent arcs to the north and south) to the western edge of the foreland belt (Fig. 1). The thermal decay time for the high temperatures of backarcs is 300-500 m.y., so the backarcs of the former subduction zones cut off by the Queen Charlotte and San Andreas transform faults in the Cenozoic still have the characteristic high temperatures. In contrast, most of the Cordilleran foreland belt lies over the cold and thick cratonic lithosphere. Many of my examples come from the southern Canadian Cordillera; in southern British Columbia the backarc extends to the Rocky Mountain Trench which is located over the thermal and lithosphere thickness boundary.

In the first part of this article I discuss problems with the continent/terrane collision model for the Cordilleran mountain belt. I then present evidence that the North American Cordilleran backarc is uniformly hot in contrast to the cold adjacent craton, the Canadian Shield. For our purposes here, 'craton' refers to regions with thermotectonic ages (i.e. the most recent widespread igneous activity, crustal deformation, and metamorphism) greater than about $500 \mathrm{Ma}$ (most of the Canadian Shield is much older), and 'current' backarcs include those where subduction is active or has terminated within the past $\sim 50$ m.y., and which are still hot. Although there are resolvable lateral variations in current crust and upper-mantle temperatures within the Cordillera and within the craton, they are very much smaller than the contrast between the Cordillera and the craton and other stable areas. In the second part of the article I discuss some of the important consequences of the high temperatures in the Cordillera and other backarcs, including the origin of their high elevations. Many important conclusions can be reached based on the simple first-order approximation of bimodal continental thermal regimes. Later

in the article I provide a short discussion of the thermal regime and its tectonic consequences in ancient backarcs with intermediate thermotectonic ages between the Cordillera and the craton, such as the Appalachian Orogenic Belt. Most of the discussion is for the North American Cordillera but many of the conclusions apply to other backarc mobile belts globally, and the study of modern backarcs such as the Cordillera gives us important insights into past processes in ancient backarc orogenic belts.

An important recent conclusion is that the lithosphere beneath the Cordillera is hot and thin $(\sim 60 \mathrm{~km})$. The region has a lithosphere thickness and thermal regime that are remarkably uniform in spite of its complex surface geology and geological history. The uniformly high temperatures and thin lithosphere are in common with most other backarc mobile belts, in contrast to the cold and thick (200-250 km) lithosphere of cratons (Fig. 1). Based especially on work by Claire Currie (e.g. Hyndman et al. 2005; Currie and Hyndman 2006), we think we know why backarcs are hot. There is inferred shallow small-scale asthenosphere convection, as modelled by Currie et al. (2004). The convection likely results from viscosity reduction by water produced and driven upward from the dehydrating subducting oceanic plate as temperature and pressure increase downdip. Only a very small amount of water $(\sim 50 \mathrm{ppm})$ is required (e.g. Karato and Wu 1993). Rippe et al. (2013) and Arcay et al. (2006) discuss how the fluid content strongly reduces the viscosity of the mantle. In any case, independent of the causes, the evidence for high temperatures and thin lithosphere in backarcs compared to cratons is quite clear and we can discuss some of the important tectonic consequences (e.g. Hyndman 2010). These include:

(1) The average elevation of the Cordillera is high even though there is no crustal root. The crust is thin, so there is a violation of simple Airy isostasy. The high elevation compared to the craton is instead supported mainly by the density reduction due to thermal expansion.

(2) Because they are hot, the Cordillera and other backarcs are tectonically weak. They are active 
mobile belts that can be deformed by plate-boundary and high elevation gravitational forces, in contrast to cold cratons that cannot easily be deformed, so remain stable for long periods of geological time. An indication of the weak Cordillera backarc lithosphere is that much of the North American seismicity is in the Cordillera where most current deformation is occurring. Another indication of backarcs being weak is that globally, continental collision deformation occurs mostly in the weak backarc side of the suture.

(3) There is widespread sporadic 'backarc' volcanism across the Cordillera, because temperatures are close to the solidus at shallow depths in the mantle. Melting may be fluxed locally by subduction water input or result from extensional stresses.

(4) The lower crust is very weak in the Cordillera and other backarcs. This weak layer allows the upper crust to detach from the mantle over large areas. Detachment of the lower crust allows the upper crust to be thrust over adjacent stable lithosphere in foreland fold and thrust belts, and also may facilitate the development of large-scale crustal oroclines that involve horizontal plane crustal bending. Many if not most oroclines may involve only the upper crust.

(5) The lower crust of the Cordillera and other backarcs are in amphibolite- to granulite-facies conditions $\left(800-900^{\circ} \mathrm{C}\right)$ at the Moho. Such high temperatures in ancient backarcs can explain the evidence that regional Barrovian metamorphism in deeply-exhumed terranes predated orogenic deformation (e.g. Thompson et al. 2001; Collins 2002); there is no "heat of orogeny". Also, the thermal contrast between backarcs and adjacent stable areas provides an explanation for some types of paired metamorphic belts.

\section{THE CONTINENTAL COLLISION MODEL FOR MOUNTAIN BELTS}

Let us start with the puzzle of the elevation of the Cordillera.

Geologists have puzzled over the elevation of mountain belts (e.g. Fig. 2) since the earliest days of scientific geology when marine fossils were found high in the mountains of Europe. How did they get there, and what lifted them up? How did they persist when erosion was recognized as an effective levelling process? There were many theories that now appear fantastic, with some quite perceptive analyses such as by the Swiss geologist Émile Argand (Argand 1924), but a simple elegant mechanism was provided only in the 1960's with the development of the theories of continental drift and plate tectonics. The formation of mountain belts was explained through continental collision (Fig. 3) (e.g. Dewey and Bird 1970). Oceanic lithosphere can subduct beneath continents because it is cold and dense compared to the warmer asthenosphere into which it penetrates. Also, oceanic crust that might resist subduction may be transformed into dense eclogite, and so is no longer buoyant relative to the mantle. When an ocean between continents (or thick-crust oceanic terranes) closes completely, the continental crust is too thick and too low a

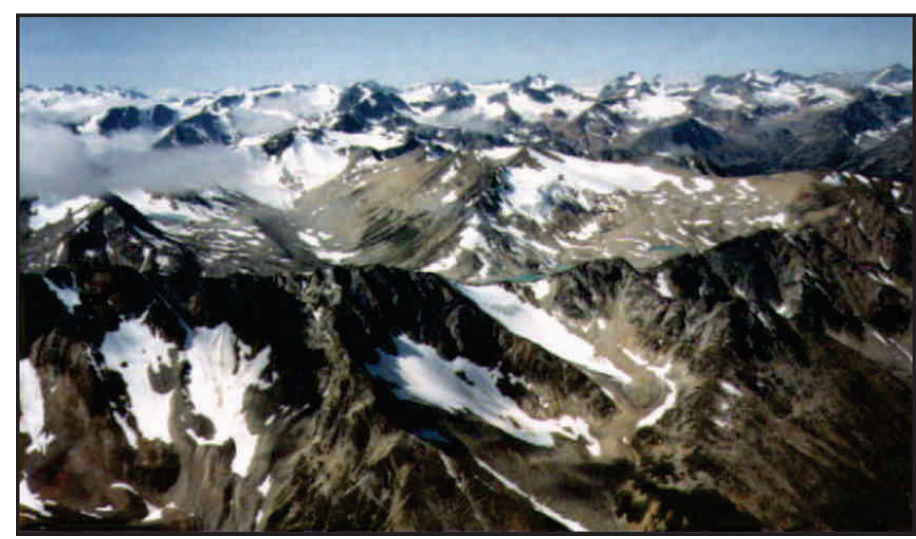

Figure 2. Aerial photo of the North American Cordilleran mountain belt. The average elevation of the belt is about $1500 \mathrm{~m}$, but the crust is thin.

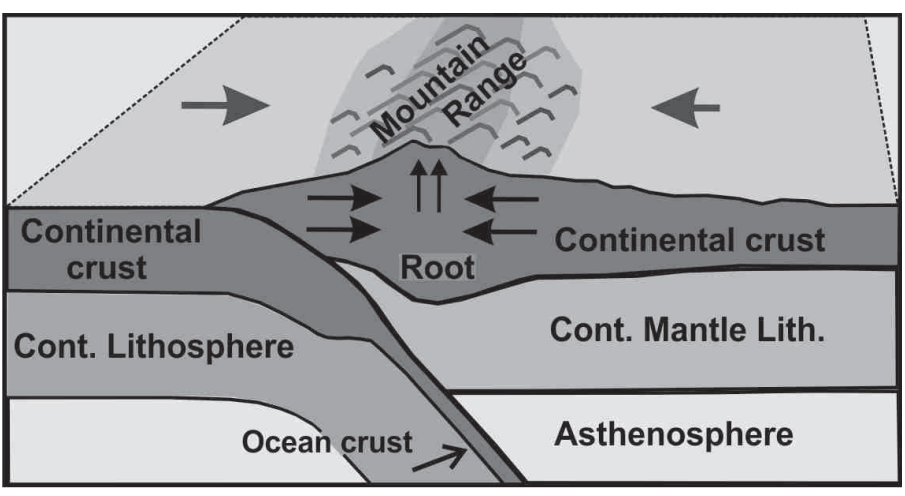

Figure 3. Model of continental collision and crustal thickening for mountain-belt formation. For the Cordillera there is no crustal root, so this is not a valid model for the high elevation.

density to subduct and there is no phase change that can increase the density of felsic materials to approach that of the mantle. Neither of the bounding crustal blocks can subduct, and the result is continental collision, crustal shortening and thickening. Ancient collisions are evident in the geological record as orogenic belts, defined by strong deformation, associated igneous activity and crustal high-temperature metamorphism. This is a very simple, elegant, and persuasive mechanism and is given in many textbooks, but let us look at this explanation for mountain belt high elevations in more detail.

In this model, the high elevations of mountain belts are supported by a thickened crustal root, similar to the deep keels of icebergs that support the height of the ice above the ocean. This is Airy Isostasy, after the English mathematician and astronomer Sir George Biddell Airy. For my discussion below, there are two primary predictions of the collision model for high mountain-belt elevations: (1) Continental (or thick-crust oceanic terrane) collision, and (2) A thick crustal root that supports the elevation. The ongoing collision of India against Asia resulting in the Himalaya Mountains and the high plateau of Tibet is the type example of this mountain-belt formation model.

First, the northward motion of India toward Asia is well recorded in paleomagnetic data, as initially shown by Edward (Ted) Irving in his Cambridge University thesis (Irving 1954) and plate models (e.g. summary by Aitchison et al. 2007). Ongoing collision, deformation and regional Himalaya-Tibet uplift are clear in high-resolution GPS position data (e.g. Bil- 
ham et al. 1997; Zhang et al. 2004), and in earthquake activity at the thrust front and to the north (e.g. Feldl and Bilham 2006). Second, a $70 \mathrm{~km}$ thick crustal root that supports the Himalayas and Tibet through Airy isostasy is well determined through seismic structure techniques (e.g. Kind et al. 2002). Total crustal thickness is almost double the global average of about $40 \mathrm{~km}$ (e.g. Christensen and Mooney 1995). This thickening is approximately enough to support the high elevations, although there is another factor, thermal expansion, that is second order for this mountain belt but is the first-order cause for the Cordillera elevation, as I discuss below. For the Himalayas and Tibet, the collisional model is convincing, but we should not be too quick to apply it globally. Are these two predictions of continental collision and unusually thick crust verified for other mountain belts?

\section{The Collision Model Applied to South and North American Mountain Belts}

The continental collision and crustal thickening model for mountain-belt formation seems so reasonable and fits the largest currently active mountain belt, the Himalayas and Tibet, so well, it has not generally been appreciated that this model is not in universal agreement with observations elsewhere. There are serious problems for each of the two other largest mountain belts, the North American and South American Cordilleras. Let us first look briefly at the South American Cordillera, the Andes. Indeed there is thick crust under the highest-elevation central portion, reaching $70 \mathrm{~km}$ (e.g. McGlashan et al. 2008), a depth similar to that in the Himalayas-Tibet, although there is much thinner crust in the northern and southern Andes (e.g. Mooney et al. 1998). Also there is current shortening and uplift evident in GPS data, in earthquake activity, and in a variety of geological data (e.g. Khazaradze and Klotz 2003). The principal problem with the Andes is that there is no current collision and there has been none for more than 100 m.y. (e.g. Beck 1988; Ramos 2010). The ongoing shortening and crustal thickening in the central region must have resulted from unusually strong stress transmission across the South American subduction thrust. I will not dwell on that collision-model problem here, but move on to the main focus of this article, the North America Cordillera.

The North American Cordillera does not have elevations as high as those of the Himalyas-Tibet or the central Andes but the region is a mountain belt, averaging about $1500 \mathrm{~m}$ above sea level (Fig. 2). As for South America, the first prediction of the continental collision model encounters problems in North America. Although there have been several past terrane-accretion events, there is no current or recent widespread collision or continental accretion along most of the Pacific margin, aside from current collision of the Yakatat terrane in a small restricted area of the Gulf of Alaska, which I discuss later. The last collision event along a significant part of the west coast was the Eocene accretion of thickened oceanic crust of the narrow Crescent-Siletz Terrane at 40-50 Ma (e.g. McCrory and Wilson 2013, and references therein). Even this terraneaccretion event occurred only along the central part of the coast from Oregon to central Vancouver Island, whereas the mountain belt extends from Mexico to Alaska.

Even more serious for the applicability of the collision and crustal thickening model is the lack of thickened crust to sup- port the Cordilleran elevation. Although the crust may have been thick in the past, it is thin now. The thin crust is the main point of my discussion below. The crust and upper-mantle structure of the Cordillera is complex, especially in the United States part, with a number of special structural and tectonic areas such as the Basin and Range extensional province, the Yellowstone hotspot (mantle plume), the quite recent Colorado Plateau uplift that resulted in the Grand Canyon, and the unusual Sierra Nevada mountains. This complexity has resulted in a tendency to focus on smaller-scale crustal variations within the Cordillera without appreciating the regional firstorder picture of thin crust compared to the adjacent central North American Canadian Shield.

\section{CRUSTAL THICKNESSES IN NORTH AMERICA AND THE ISOSTASY PROBLEM}

My appreciation that there was a problem with the crustalthickening model for the Cordillera elevation came some 20 years ago from the Canadian Lithoprobe Program, an exceptionally successful multidisciplinary geoscience effort involving academia, Federal and Provincial geological surveys, and industry geologists and geophysicists. The program was directed at the geophysically-defined deep-crustal structure and its associations with surface geological structure. There are two primary techniques for crustal and upper-mantle seismic structure that usually gave good estimates of the depth to the base of the crust, the Moho. They are deep seismic reflection (mainly 'Vibroseis,' as used in the petroleum industry) and wide-angle or refraction seismic surveys. The reflection times from subsurface layers give the depth, providing the seismic velocity of the section is known. In some areas the Moho is seen as a strong reflector, and in others the base of the crust may be defined by a change in the reflection character with depth, as the crust commonly has complex reflections from composition inhomogeneities, whereas the upper mantle is more uniform and seismically transparent. The second method, wide-angle or seismic refraction, generally uses large explosion sources with ground motion recorded at considerable distances. This method gives seismic velocities with depth, as well as defining layering within the earth, but it has low spatial resolution. These methods, as well as more recent work using receiver functions (e.g. Cassidy 1995) and surface-wave tomography (e.g. Kao et al. 2013), generally give consistent crustal thicknesses.

Figure 4 shows results from two areas where there are welldefined crustal thicknesses, the central Cordillera just north of the U.S. border and an area in the craton of the central Canadian Shield (e.g. Clowes et al. 1995; Cook et al. 2010, and references therein). The craton immediately adjacent to the Cordillera is covered by a thick layer of sediments which complicates isostasy calculation, so I have used an example from the exposed craton further to the east. However, in the Western Canada Sedimentary Basin, correcting for the sediment load and thickness gives an elevation and crustal thickness in agreement with the exposed craton. The Cordillera has an average surface elevation of about $1500 \mathrm{~m}$ and the Shield has an average elevation just above sea level. The surprising result is that the high-elevation Cordillera site has a thinner crust (about $32 \mathrm{~km}$ average), compared to the shield site (about 40 $\mathrm{km})$, which is a clear violation of simple Airy Isostasy. There is no Cordilleran mountain root. 
These sites are not local anomalies. The averages from a compilation of crustal thickness and surface elevation data for North America by Hasterok and Chapman (2007) are $33 \pm 5 \mathrm{~km}$ for the Cordillera and $40 \pm 4 \mathrm{~km}$ for the stable Canadian Shield. Similar crustal thicknesses in the region of the sections in Figure 4 have been obtained from receiver functions that use phase conversions at the Moho from distant earthquake sources (e.g. Cassidy 1995), and noise tomography surface wave inversions that use a range of frequencies to resolve velocities at different depths (e.g. Kao et al. 2013). The crustal thickness

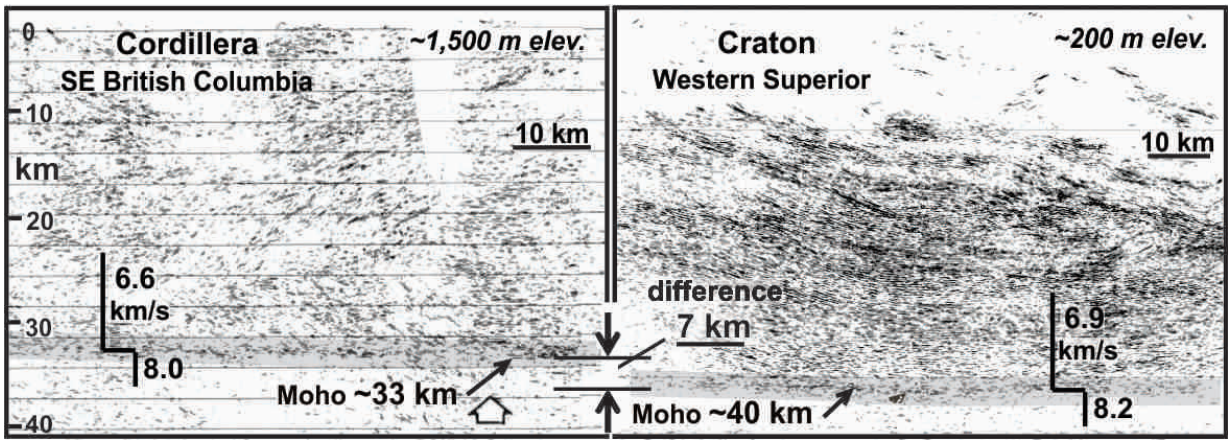

Figure 4. Seismic reflection and simplified wide-angle seismic structure estimates of crustal thickness; examples from the southern Canadian Cordillera and the adjacent craton (after Cook et al. 2010). The high elevation Cordillera has a $7 \mathrm{~km}$ thinner crust than the near sea level craton.

contrast in the western U.S.A. is very well resolved from USArray closely-spaced seismic stations (Levandowski et al. 2014) that indicate a clear division between the Cordillera $(30-35 \mathrm{~km})$ and the stable area to the east (40-45 km) (Fig. 5).

Most of the Cordilleran Belt has crustal thicknesses of $30-35 \mathrm{~km}$ but there are significant variations in a few areas which can be used to illustrate the difference in buoyancy between the Cordillera and Shield more graphically. Figure 6 shows the relation between crustal thickness and elevation using data from the Hasterok and Chapman (2007) compilation (Hyndman and Currie 2011). The data have been corrected for the usually small effect of differences in crustal density (i.e. Pratt Isostasy), using average crustal seismic velocities and the general relation between density and velocity. Within the Cordillera and within the Shield, there is a good linear relation between crustal thickness and elevation, just as predicted by Airy Isostasy. The slope of the line defines the density contrast at the Moho, which is similar for both areas and close to the value predicted for the expected main rock types, i.e. gabbroic lower crust and peridotite upper mantle.

Surprisingly the two lines are systematically offset by 1600 $\mathrm{m}$ (Fig. 6). Elevation in North America is remarkably bimodal. The Cordillera is about $1600 \mathrm{~m}$ higher than the Canadian Shield for the same crustal thickness. The variations from the best-fit line relating elevation and crustal thickness within each of the two areas are quite small in spite of the geological complexities. The locations shown in the figure were partly chosen to give a wide elevation range to define the lines. The variability in crustal thickness is generally quite low. I emphasize that these data are for current crustal thicknesses. The Cordillera may have had greater thicknesses and elevations at times of shortening, such as during the Laramide Orogeny when the foreland thrust belt was active (see Bao et al. 2014). To illustrate the abrupt contrast in crustal thickness between the Cordillera and the craton, Figure 7 shows the crustal transition across southeastern British Columbia and western Alberta (Hyndman and Lewis 1999; see also Burianyk et al. 1997; Cook et al. 2010). The transition is centred at about the Rocky Mountain Trench (e.g. van der Velden and Cook 1996). The Moho beneath the Cordillera to the west is at $32-34 \mathrm{~km}$. Because of the load of the overthrusted upper Cordilleran crust and sedimentary thrust sheets, the lithosphere of the adjacent craton is depressed to a Moho depth of about $50 \mathrm{~km}$ (see Stockmal and Beaumont 1987, for models of such overthrusting). This thickness is made up of a normal-thickness

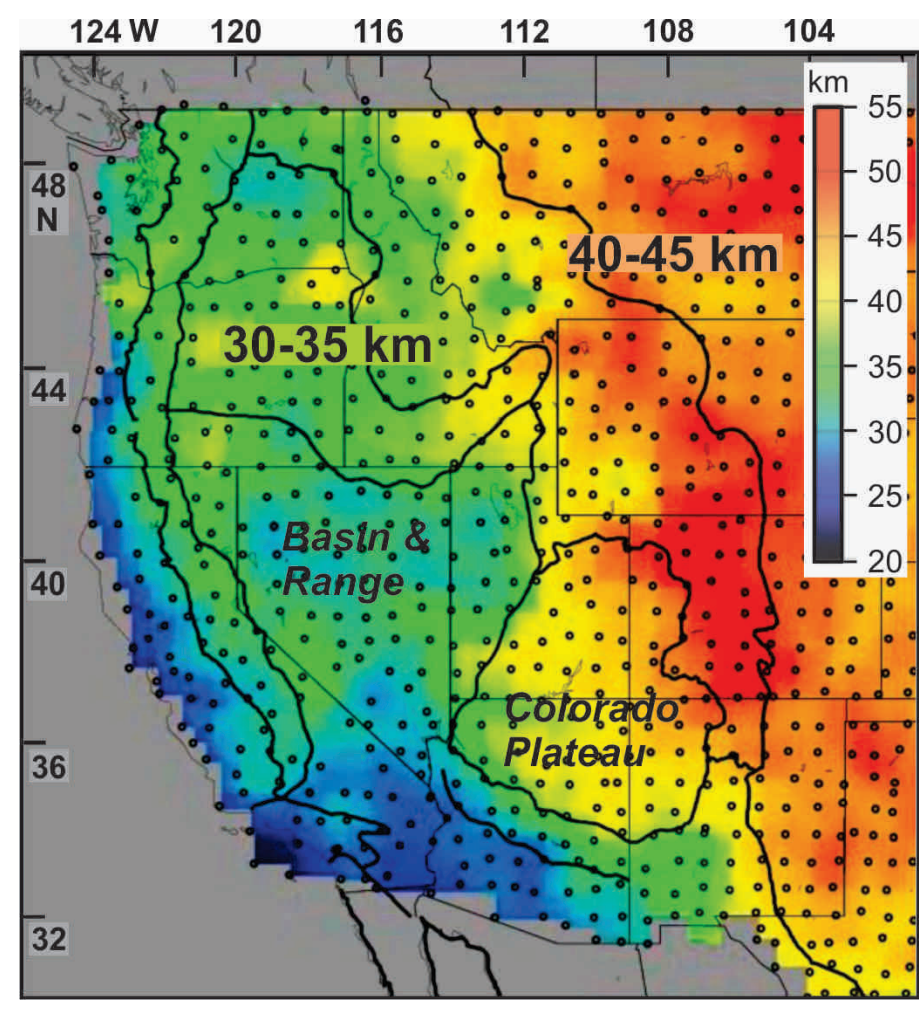

Figure 5. Crustal thickness in western United States showing the remarkably uniformly thin Cordilleran crust and thicker craton crust based on US Array seismic data (after Levandowski et al. 2014)

craton crust of about $40 \mathrm{~km}$, overlain by the about $10 \mathrm{~km}$ thick Western Canada Sedimentary Basin section. In spite of the more than $15 \mathrm{~km}$ contrast in crustal thickness, there is almost no change in elevation or in Bouguer gravity. The crustal thickness contrast is balanced by the thermal contrast, as I discuss below. The figure also shows the predicted elevation for the Cordillera using the crustal thickness-elevation relationship for the cold craton in Figure 6. The predicted elevation for the $32-34 \mathrm{~km}$ thick Cordilleran crust, if it had a cold craton thermal regime, would be below sea level. The sharpness of the transition is indicated in a detailed shear wave tomography study of the area by Bao et al. (2014). As they illustrate, there is a sharp velocity contrast and a sharp truncation of magnetic anomalies at the Rocky Mountain Trench.

There is an interesting related comparison between the hot, thin lithosphere beneath western Europe (crustal thicknesses 


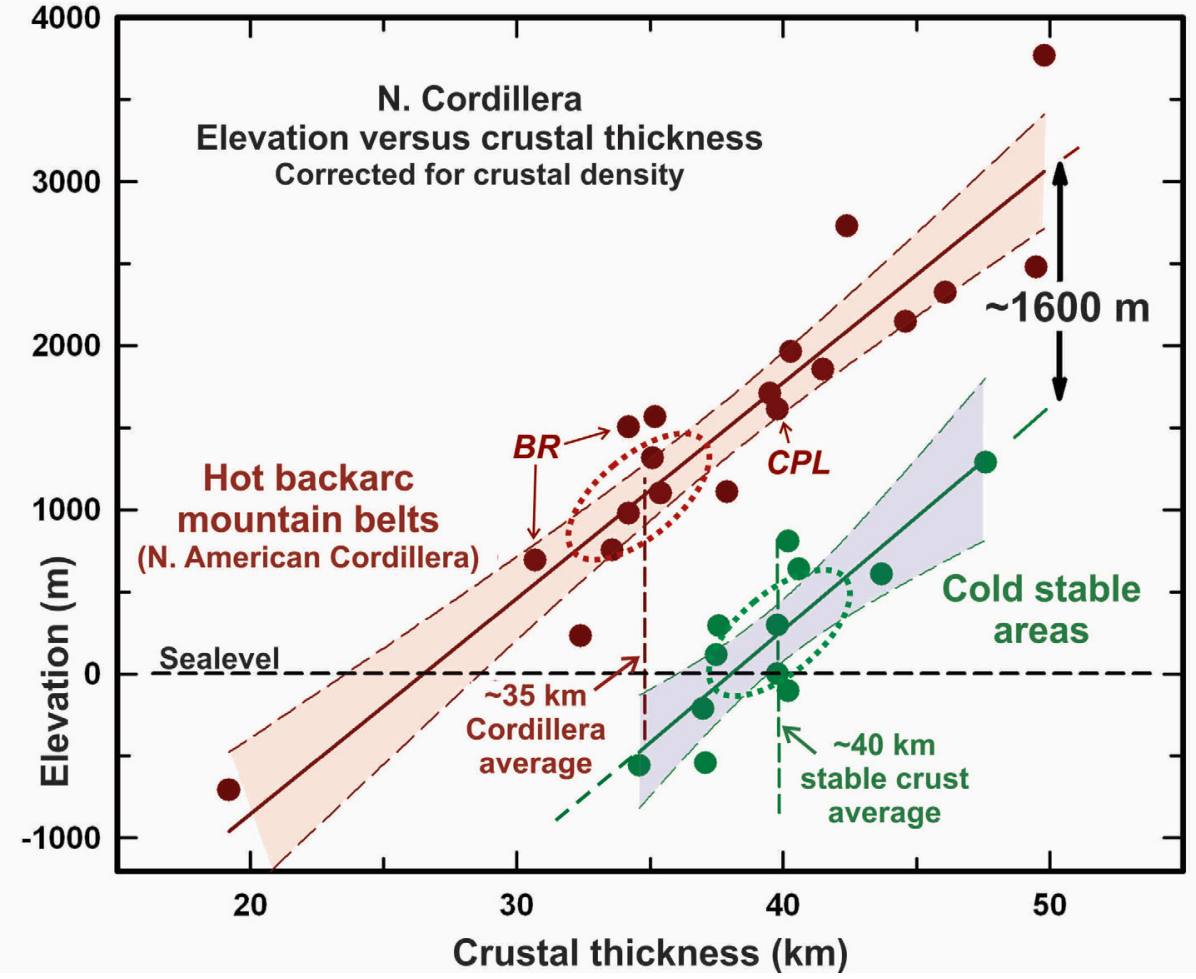

Figure 6. Elevation versus crustal thickness for the Cordillera and craton showing the $1600 \mathrm{~m}$ difference in elevation for the same crustal thickness $(\mathrm{BR}=$ Basin and Range; $\mathrm{CPL}=$ Colorado Plateau) (after Hyndman and Currie 2011).

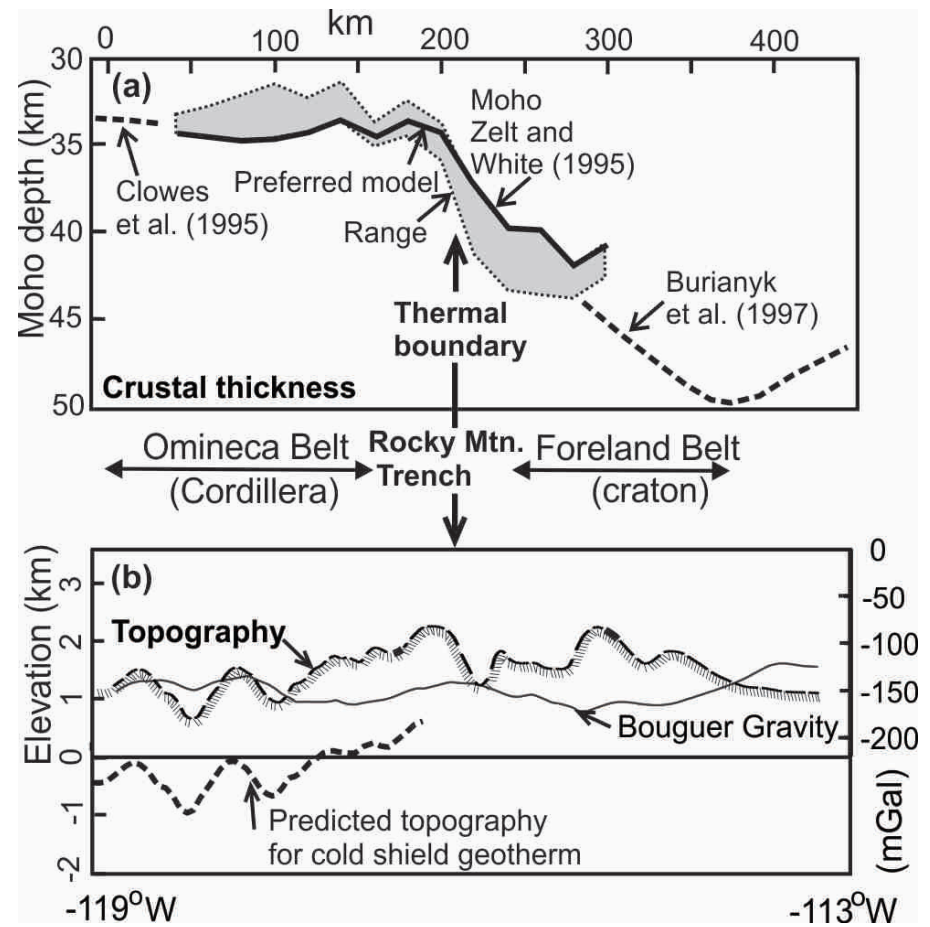

Figure 7. (a) The abrupt eastward increase in crustal thickness at the lithosphere thermal boundary beneath the Rocky Mountain Trench. (b) The small associated change in elevation and Bouguer Gravity across the crustal thickness boundary (after Hyndman and Lewis 1999). See also Cook et al. (2010), and Bao et al. (2014).

of about $30 \mathrm{~km}$ ), compared to the cold Fennoscandian Shield to the northeast (crustal thicknesses of $40-45 \mathrm{~km}$ ). The crust is generally somewhat thinner in western Europe compared to the North American Cordillera so the elevation is lower and there is little difference in elevation beneath western Europe and the adjacent shield (see figure 2 of Tesauro et al. 2008). Although corrections for variations in crustal density have not been applied, the averages for these two regions agree very well with our plots of crustal thickness versus elevation for North America. Western Europe, most of which is a current or thermally recent backarc, is equivalent to the Cordillera, and the Fennoscandian Shield is equivalent to the Canadian Shield (Fig. 6). The elevation difference between the two regions for the same crustal thickness is again about 1600 m.

\section{CRUST AND UPPER MANTLE TEMPERATURES, AND THERMAL ISOSTASY}

I now turn to the origin of these differences in crustal thickness and elevation.

The controls of continental elevation have been an important discussion for many years. There are two well-recognized factors, i.e. crustal thickness (Airy Isostasy) and crustal density (Pratt Isostasy). In addition, there has been much work on the role of mantle flow traction and mantle dynamics (e.g. reviews by Braun 2010; Flament et al. 2013; Becker et al. 2013). Although the latter may be important, as I show below it must be subordinate to the effect of thermal isostasy in generating the elevation difference between the Cordillera and adjacent craton. Also, for the Cordillera and other hot backarcs, the estimated asthenosphere viscosities appear to be too low to allow significant lithosphere basal traction and for convective buoyancy forces for that area (see also Levandowski et al. 2014).

It has been recognized for many years that the temperature in the crust and upper mantle can significantly affect the rock densities through thermal expansion, and therefore affect surface elevation. Hotter crust and upper mantle rocks will have lower densities, and so float higher. Much of the credit for elegant mathematical modelling and rigorous data analysis of the thermal effect is due to Art Lachenbruch from the U.S. Geological Survey (e.g. Lachenbruch and Morgan 1990). Many conceptual models of subduction zones have regional high temperatures near the volcanic arc, but we now recognize that there is only a small high-temperature thermal anomaly associated with the arc (e.g. Hyndman et al. 2009) except immediately around the volcanic centres. The high temperatures extend uniformly across the entire backarc, including the volcanic arc. In the next sections, I first describe the principal constraints on temperature in the crust and upper mantle, and then the effects of these temperatures in terms of elevation and other consequences.

\section{Surface Heat Flow Temperature Estimates}

Until recently the main constraint on deep-crustal and uppermantle temperatures was the surface heat flux from the earth, 
commonly estimated from temperatures measured down deep boreholes and the thermal properties of core samples of the rocks penetrated, as measured in the laboratory. These heat-flux estimates can be used to estimate lithosphere thickness (e.g. Chapman and Pollack 1977). Using this constraint on deep temperatures, Hasterok and Chapman (2007) showed that elevation is related to surface heat flow in the way expected for thermal isostasy. However, extrapolating surface heat flow to deep temperatures has a large uncertainty, especially due to variations in near-surface radioactive heat generation, which result in a considerable scatter in the relationship. The heat generation from the natural radioactivity of the unstable isotopes of uranium, thorium and potassium is commonly concentrated in the upper crust, so contributes directly to the measured surface heat flux but has only a small effect on the deep temperatures. This uncertainty can be much reduced if we have measurements of radioactive element abundance, and can allow for variations in radioactive heat generation in upper crust rocks.

One area where we have good radioactive heat generation measurements, as well as detailed heat flux data, is across the southern Canadian Cordillera, especially by Trevor Lewis (e.g. Lewis et al. 1992; Hyndman and Lewis 1995; also see Lewis et al. 2003, for the northern Canadian Cordillera). David Blackwell and colleagues showed similar high heat flow in Washington and Oregon (e.g. Blackwell et al. 1990). Figure 8 shows the heat flux with a first-order correction for the effect of variations in near-surface radioactive heat generation, in a profile across the Cordillera. Considerable scatter remains, but the contrast between the nearly laterally uniform high heat flow across the Cordillera and the low heat flow for the Shield is clear. Heat flow in the Cordillera is almost twice that of the shield. The Western Canada Sedimentary Basin to the east of this Cordillera profile overlies the shield and the thick sedimentary section, coupled with fluid-advection effects, makes reliable measurements difficult (see discussion by Majorowicz et al. 2014), so I show an average heat flux for the crystalline rocks of the shield exposed further to the east. Majorowicz et al. (2014) reported one high-quality heat flow from a $2.2 \mathrm{~km}$ deep hole into the basement rocks beneath the Basin that gave a heat generation-corrected heat flow close to the average for the exposed shield. Mareschal and Jaupart (2004) have shown that most of the surface heat-flow variation in the shield is due to variations in upper-crustal heat generation, so there are only small lateral variations in its deep temperatures (also see Artemieva and Mooney 2001).

Other temperature constraints in our toolbox include two that I illustrate: seismic velocity in the upper mantle (especially $V s$ mantle tomography), and temperatures from mantle xenoliths at their depth of origin. Others that give consistent results are: $T e$, the mainly temperature-controlled effective elastic lithosphere thickness from gravity-topography coher-

ence (e.g. Hyndman et al. 2009); the seismic and electrical thickness of the lithosphere, which are mainly thermally controlled (e.g. Eaton et al. 2009); low effective viscosities in the shallow mantle; the mainly thermally-controlled maximum depth of seismicity; and the depth of the Curie temperature estimated from magnetic surveys. Only the first two constraints are discussed in the following section.

\section{Temperature Control of Seismic Velocity in the Upper Mantle}

Within the continental crust, seismic velocities are mainly controlled by rock composition. However, in the upper mantle the velocity is mainly controlled by temperature and the effect of temperature on velocity from laboratory data can be used to estimate upper mantle temperatures. Higher temperatures give lower velocities. The second-order effect of lateral variations in upper-mantle composition can be corrected, especially using mantle compositions from xenoliths. A sometimes complicating factor is the presence of partial melt, especially in parts of the U.S. Cordillera, such as beneath the Yellowstone region, so I show mainly the temperatures for the Canadian Cordillera where partial melt appears generally not to be sufficiently wide spread to be important.

Temperatures can be estimated from both compressional wave velocities, $V_{p}$, and shear wave velocities, $V_{s}$. I give temperature-depth results only from shear-wave seismic tomography that uses ground surface waves moving across an area. This method generally has used earthquake-generated waves but has recently been extended to use 'noise' signals moving across an array of recording stations, with the 'noise' usually interpreted to be generated in the ocean basins. Many intersecting wave paths give velocity maps over large areas, and the depth of penetration depends on the frequency, which allows estimation of velocity-depth profiles and 3D temperatures. 


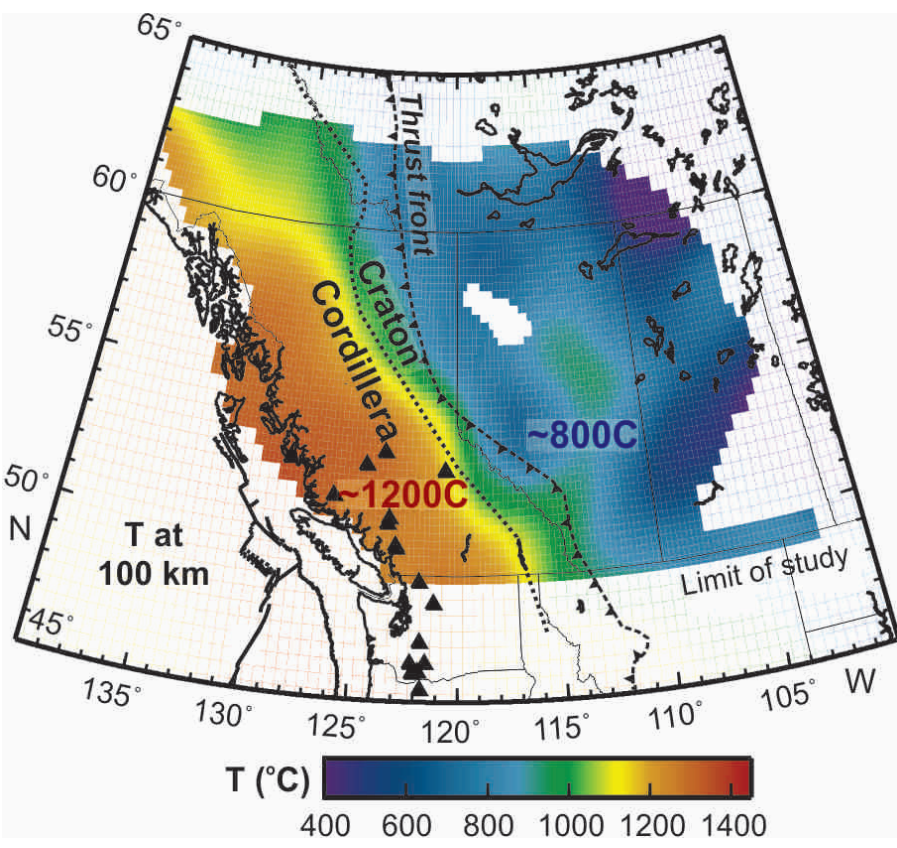

Figure 9. Temperatures at $100 \mathrm{~km}$ depth across the southern Canadian Cordillera (about $1200^{\circ} \mathrm{C}$ ) and adjacent craton (about $800^{\circ} \mathrm{C}$ ) estimated from mantle seismic velocities (after Hyndman et al. 2009).

Figure 9 illustrates the temperatures at a depth of $100 \mathrm{~km}$ for western Canada, based on a velocity study led by Andrew Frederiksen, University of Manitoba, and temperatures calculated by Claire Currie, at the University of Alberta (e.g. Hyndman et al. 2005). The inferred temperatures are remarkably high and laterally uniform across the Cordillera and much lower and quite uniform in the adjacent craton (e.g. Hyndman et al. 2009). Bao et al. (2014) show that the Cordillera-craton mantle velocity contrast (and therefore temperature contrast) in the mantle is very sharp at the Rocky Mountain Trench. Figure 10 shows the average and variability of the temperaturedepths for the Canadian Cordillera and for the western craton. Some of the variability in the results represents real temperature variation and some comes from measurement uncertainty. In any case, the variability within each region is much smaller than the difference between the two regions.

\section{Xenolith Temperature-Pressure (Depth)}

Small samples of rocks from the deep crust and upper mantle occasionally are carried to the surface through kimberlite pipe eruptions ('diamond pipes') in the craton, or entrained in volcanic magmas in the Cordillera. Commonly the exhumation rates are rapid enough that chilling retains the mineral equilibria representative of the temperature and pressure (depth) at their source, allowing calculation of temperature-depth profiles at the time of emplacement. Depth calculations are much more reliable for the xenoliths from cratonic regions, which have minerals with pressure-sensitive equilibria than for the Cordillera where the depths usually must be estimated indirectly.

Upper-mantle xenoliths have been recovered from numerous localities in the Cascadia backarc and the adjacent craton. An early study yielded $1000^{\circ} \mathrm{C}$ at $40 \mathrm{~km}$ depth, increasing to $1300^{\circ} \mathrm{C}$ at $60-70 \mathrm{~km}$ (Ross 1983), so the very high temperatures and thin lithosphere in parts of the Cordillera were

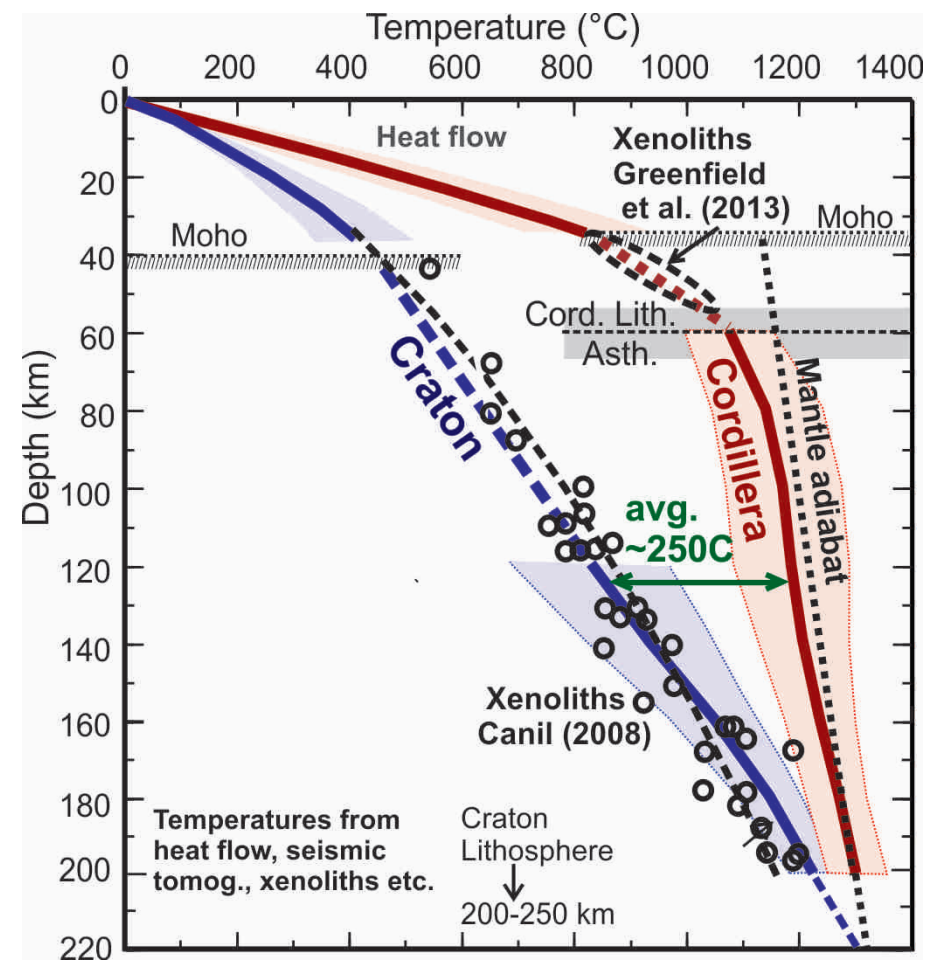

Figure 10. Average temperature-depth profile for the Canadian Cordillera and adjacent craton from heat flow, seismic tomography velocities (red and blue lines; variability, shaded areas), and xenoliths (black circles and dashed lines) (after Hyndman et al. 2009). There is a maximum difference between the Cordillera and the craton of about $400^{\circ} \mathrm{C}$ at $100 \mathrm{~km}$ and an average temperature difference to $220 \mathrm{~km}$ of about $250^{\circ} \mathrm{C}$

inferred over 30 years ago by this method. Subsequently, Saruwatari et al. (2001) found $900-1040^{\circ} \mathrm{C}$ at $1.2-1.6 \mathrm{GPa}$ (35-50 km depth) for southern British Columbia to Alaska. Harder and Russell (2006) studied the Llangorse/Edziza volcanic field (northwest British Columbia) and found a minimum temperature of $800-850^{\circ} \mathrm{C}$ which provides an estimate for the Moho and a maximum of $1050-1100^{\circ} \mathrm{C}$ which gives an estimate for the base of the lithosphere. They produced model geotherms that are in good agreement with those from our seismic velocity estimates; they estimated the base of the lithosphere at 52-66 km (Fig. 10). For southern British Columbia, Greenfield et al. (2013) estimated a Moho temperature at 33 $\mathrm{km}$ of $825 \pm 25^{\circ} \mathrm{C}$, with $1060^{\circ} \mathrm{C}$ at $48 \mathrm{~km}$. For all the Cordillera studies, high temperatures are inferred, with the convective adiabat at about $60 \mathrm{~km}$, where rocks are weak enough for small-scale convection, close to first melting.

For the craton and stable platform, numerous studies give temperatures from mantle xenoliths (e.g. MacKenzie and Canil 1999; Canil 2008, and references therein) that are very consistent with temperatures from $V_{s}$ (Fig. 10). There are wellresolved lateral variations but they are small compared to the contrast with the Cordillera. Other cratons globally give similar temperatures (e.g. Griffin et al. 2004), i.e. the base of the thermal lithosphere is usually at $200-250 \mathrm{~km}$. This depth is similar to that obtained for the base of the lithosphere from seismic and magnetotelluric data (e.g. Eaton et al. 2009).

These results show that there is a large difference in the temperatures at the base of the crust for the cold shield $\left(400-500^{\circ} \mathrm{C}\right)$ compared to the hot Cordilleran backarc $\left(800-850^{\circ} \mathrm{C}\right)$; approximately a $400^{\circ} \mathrm{C}$ difference. I discuss only 
the coolest case of the older cratons here, mainly the Archean from North America. However, Paleozoic stable areas are only slightly warmer than older regions. I discuss them briefly later. The degree to which the thermal regimes of the continents are bimodal is quite impressive, leading to some important consequences.

\section{ORIGIN OF CORDILLERA BACKARC HIGH TEMPERATURES}

The high temperatures in backarcs like the Cordillera have been explained by rapid upward convective heat transfer beneath a thin lithosphere (see Hyndman et al. 2005, for discussion). The first suggestion of this process I have found was by Hasebe et al. (1970) who were concerned with the high heat flow in the Japan Sea backarc. Based on high heat flow, high electrical conductivity and other results that presented strong evidence for high temperatures and partial melting beneath the Canadian Cordillera, Gough (1986) proposed "mantle upflow tectonics." Many models of backarc convection have assumed one large-scale circulation cell driven by the downward traction and thermal effects of the cold downgoing oceanic plate. This model is conceptually reasonable but it has proved difficult to produce the observed uniform high heat flow across the backarc with such models (e.g. Kukačka and Matyska 2008). Heat should be lost from the top of the cell such that temperatures and surface heat flow decrease toward the arc, unless the convection speed is much faster than plate motion rates. This decrease is not observed. Regional small-scale convection that maintains adiabatic temperatures below about $60 \mathrm{~km}$ seems to be required, with flow rates faster than relative plate-motion rates (e.g. Nyblade and Pollack 1993; Currie et al. 2004; Arcay et al. 2006). Figure 8 shows a schematic convection model along with the southern Canadian Cordilleran heat flow. In a few areas such as the Basin and Range province, present or recent crustal extension has an additional thermal effect (e.g. Lachenbruch and Sass 1978). Similarly, in oceanic backarcs where extension is occurring, it is difficult to separate the thermal effect of extension from that of convective heat transport in the underlying shallow asthenosphere. However, Watanabe et al. (1977) suggested that even in these basins, small-scale convection is needed to explain the thin lithospheres and the high heat flow that has been maintained for long times after the basins opened.

An explanation for shallow vigorous convection beneath backarc lithospheres is that the mantle viscosity is substantially lowered by incorporation of water and other volatiles expelled from the underlying subducting oceanic plate. The backarc convection system is poorly understood, but vigorous convection may mix the water throughout the whole backarc asthenosphere wedge. Another possibility is that episodes of flat-slab subduction carry water far inland and initiate smallscale convection. Mantle rocks containing even quite small amounts of water in the mineral structure $(>50 \mathrm{ppm})$, have a substantially lower effective viscosity than dry mantle rocks (e.g. Karato and Wu 1993). Dixon et al. (2004) summarized the evidence for very low mantle viscosity beneath the Cordillera current and recent backarc of the western U.S.A. and concluded that such low viscosities require significant water in the upper mantle, as well as high temperatures that are close to the solidus. In areas where the landward boundary of the backarc is a craton or an old platform, such as western North Ameri$\mathrm{ca}$, the asthenosphere convection may be limited landward by thick, refractory lithosphere. The original craton rifting and associated asthenosphere upwelling may have extended and heated a considerable width of the margin of the craton or platform. This would have allowed subsequent backarc thermal convection to continue beneath the thinned region to the edge of the unextended craton lithosphere. Royden and Keen (1980) illustrate such margin lithosphere thinning and heating from craton rifting by the opening of the Labrador Sea ocean basin between Labrador and Greenland. The backarc also may be widened by the addition of accreted terranes, such as has occurred in western North America.

I note that globally there are a few cool backarcs, mainly where there is flat-slab subduction such that there is no space for small-scale convection between the backarc lithosphere and the underlying nearly-horizontal subducting slab (discussion by Currie and Hyndman 2006). These areas also are characterized by little or no arc volcanism. For the Peru example, see Gutscher et al. (2000).

\section{DURATION OF HIGH TEMPERATURES IN FORMER BACKARCS}

In the discussion and data shown above, I included the northern Canadian Cordillera in the backarc although subduction was cut off and stopped on that margin at $\sim 40-50 \mathrm{Ma}$ with the development of the transform Queen Charlotte Fault system (e.g. Engebretson et al. 1985; Hyndman and Hamilton 1993; McCrory and Wilson 2013). However, backarcs cool quite slowly following the termination of subduction such that the estimated lower-crust and upper-mantle temperatures in this area are little different from those to the south, landward of the presently-active Cascadia subduction zone. The same is true in California where subduction was cut off more recently by the San Andreas Fault system. There must be a finite life to the high temperatures in backarc mobile belts after the source of heat is removed, as most ancient mobile belts active in the Paleozoic or earlier no longer exhibit the high temperatures characteristic of modern backarc lithosphere. In the backarc convection model, the vigorous free convection should decline following the termination of subduction and the loss of water as a flux for convection. The processes involved are undoubtedly complex, including slab window and slab break-off effects, and may take tens of millions of years. However, lithosphere cooling and thickening are probably conductive following the increase in upper-mantle viscosity due to water loss through partitioning into arc and backarc melt fractions, and through upward diffusion. The cooling time constant may be estimated from compilations of heat flow and inferred lithosphere temperatures (Fig. 11a) and elevation (Fig. 11b) compared to the age of the most recent thermotectonic event (igneous activity, metamorphism, volcanism, etc.) (e.g. Pollack et al. 1993; Nyblade and Pollack 1993; Pavlenkova 1996; Artemieva and Mooney 2001). Much of the variability for similar ages comes from variable upper-crust radioactive heat generation that has only a small effect on deep temperatures. The thermotectonic age is assumed to correspond approximately to the time since termination of subduction and therefore of water input. The most rapid decrease in heat flow appears to be in the several hundred m.y. following the last thermotec- 
(a)
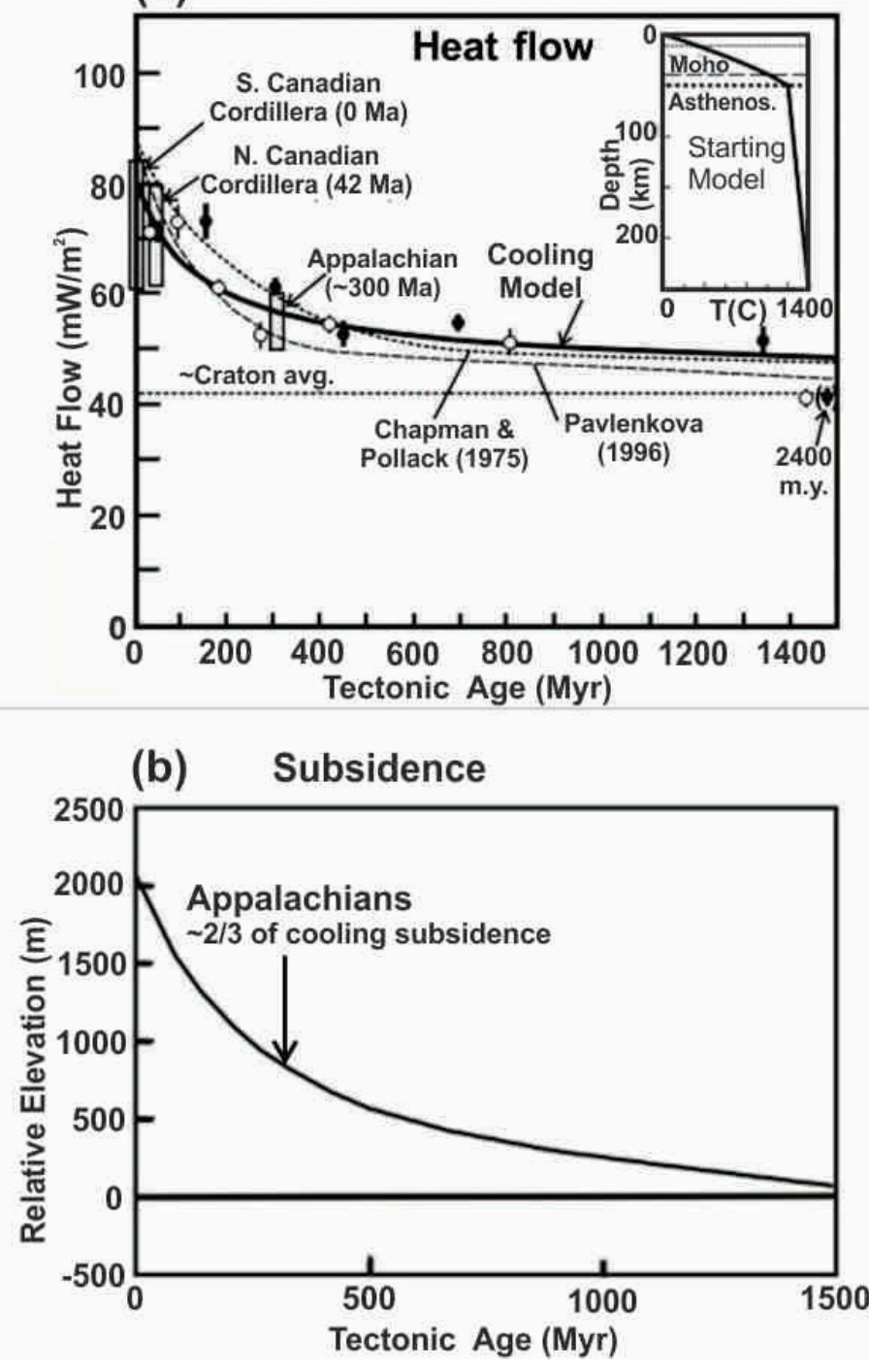

Figure 11. (a) The decay of backarc high temperatures. The heat flow from a simple cooling model is compared to heat flow versus thermotectonic age (after Currie and Hyndman 2006). (b) Simple model thermal elevation decay; there is general agreement for the Appalachian former backarc, with a model and current elevation of $600-800 \mathrm{~m}$.

tonic event, and the data suggest a 300-500 m.y. time constant, (i.e. the time for there to be $\sim 37 \%$ remaining of the total change) (see also Sleep 2005). A similar cooling and lithosphere thickening time is suggested by several examples.

The Appalachian former backarc mobile belt, in which the last significant deformation occurred at about $300 \mathrm{Ma}$, is now cool and stable. Although heat flow and other thermal data suggest that it is still somewhat warmer than the cratons (e.g. Pollack et al. 1993), at least some of the difference may be due to greater upper-crust heat generation (Mareschal and Jaupart 2004). The residual thermal elevation above that for the craton, however, remains quite significant at 600-800 m (Fig. $11 b)$. In contrast, the northern Canadian Cordillera, where margin subduction was cut off by the Queen Charlotte-Fairweather transform fault zone in the Eocene, 40-50 Ma, still has high heat flow and inferred high temperatures at depth (Lewis et al. 2003), similar to currently active backarcs (Fig. 9).
Currie and Hyndman (2006) used a simple conductive model with an initial thin backarc lithosphere and an underlying adiabatic asthenosphere to illustrate these features (Fig. 11). This model is the limiting case of abrupt termination of convection to a depth of $250 \mathrm{~km}$ (approximate thickness of craton lithosphere) at the time of termination of subduction. The heat flow data are not corrected for variations in uppercrust heat generation, and the effect of erosion of the highradioactivity upper crust should give a somewhat lower heat flow at longer times than the simple cooling model. The heat flow as a function of age predicted by the model is in general agreement with that observed (Fig. 11), which suggests that the termination of shallow free convection generally occurs only a few tens of millions of years after subduction stops.

\section{CONSEQUENCES OF THE HIGH TEMPERATURES IN THE CORDILLERA AND OTHER BACKARCS}

In addition to the high elevation discussed above, there are numerous other consequences of the crust and upper-mantle high temperatures in the Cordilleran backarc that I will now discuss. These have wide implications for processes in modern orogenic belts and also for their ancient analogues.

\section{Thickness and Strength of the Lithosphere; Weak Mobile Belts and Seismicity}

\section{The Effect of Temperature on Lithosphere Strength}

The weakness of the Cordillera backarc is well illustrated by its current and recent complex deformation (Fig. 12). It is a mobile belt. Most North American crustal seismicity occurs in the Cordillera, reflecting the widespread current deformation. There is oblique extension in the Gulf of California, where the crust is being rifted and extended, and new ocean crust is forming. In near-coastal California, the San Andreas Fault zone is a broad zone of shearing (at about $5 \mathrm{~cm}$ per year) with westernmost California moving northward as part of the Pacific Plate. To the northeast, the Basin and Range province is a broad region of block faulting, that is extending at a rate of about $1 \mathrm{~cm} / \mathrm{yr}$. Along the coast of Oregon, the Cascadia forearc sliver is moving to the northwest at about $3 \mathrm{~mm} / \mathrm{yr}$ and colliding with a stronger Vancouver Island, resulting in crustal seismicity in Puget Sound and the southern Georgia Strait. In the corner of the Gulf of Alaska, the Yakutat block is colliding with North America resulting in the continent's highest elevations, the St. Elias-Chugach mountains near the coast. This collision is also concluded to result in strain transfer across the Cordillera to the current thrusting and high seismicity in the Mackenzie Mountains at the eastern foreland (Mazzotti and Hyndman 2002). The northern Cordillera example shows the concentration of North American seismicity in the Cordillera. There is much lower seismicity and earthquake hazard in eastern North America (e.g. Frankel et al. 2000; Adams and Atkinson 2003).

The Cordillera has a long history of varied past deformation, including the widespread Laramide thrusting at the Cordillera Rocky Mountain front, and strike-slip faulting in the north-central Cordillera. The complex tectonic evolution of the belt is mainly in response to changing plate-boundary forces on the west coast, where the Pacific and North American plates interact. 


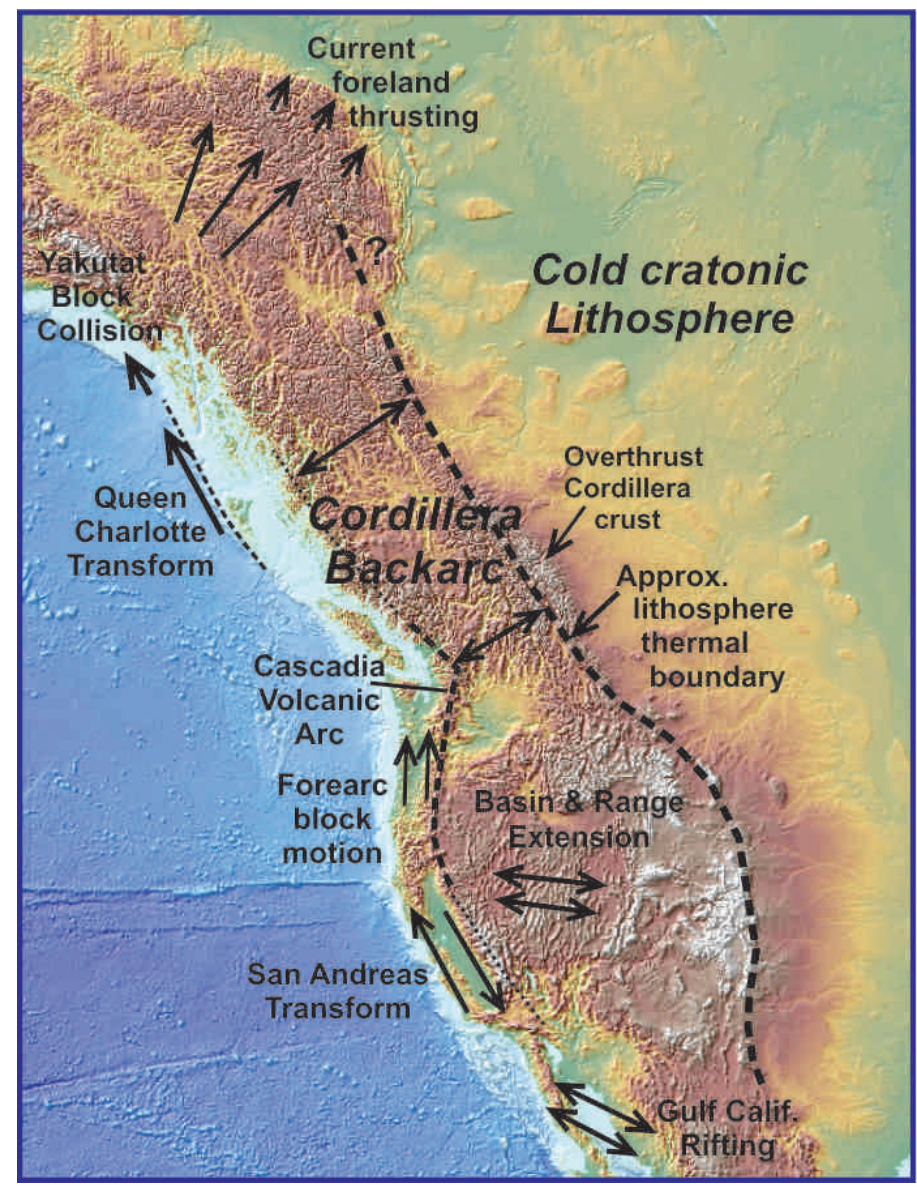

Figure 12. The Cordilleran backarc mobile belt illustrating the ongoing deformation, strike-slip faulting, normal faulting (extension), and thrust shortening (modified from Hyndman et al. 2005).

Along with deformation forces, lithosphere strength is a primary control of where tectonic deformation and seismicity occurs, and the nature of deformation processes. Lithosphere strength increases with depth in the shallow cool frictional regime because of the downward-increasing load on fault surfaces, and is not significantly related to composition or temperature. However, at greater depths where there is ductile deformation, temperature is the most important control (e.g. Ranalli 1995). Therefore, strength in the ductile regime decreases with depth, except for a downward step increase in strength at the Moho due to the change to the stronger mantle rock type. In the shallow frictional regime, the principal variable is the pore pressure, which can range from hydrostatic (i.e. porosity is connected to the surface) to lithostatic (i.e. porosity is not connected and the pore pressure is the load of the overlying rock). Townend and Zoback (2000) argued that in the frictional upper section, at least of cratons, the porosity is connected to the surface by fractures and other connected porosity, and pore pressure is generally close to hydrostatic. An estimate of the strength of the lithosphere as a function of depth in the high-temperature Canadian Cordilleran backarc and the adjacent low-temperature Canadian Shield by Stephane Mazzotti and others is shown in Figure 13 (see Flück et al. 2003; Lewis et al. 2003; Hyndman et al. 2009). In this simple model, the upper crust follows the Byerlee Law criterion for brittle fault sliding (e.g. Ranalli 1995) with hydrostatic pore

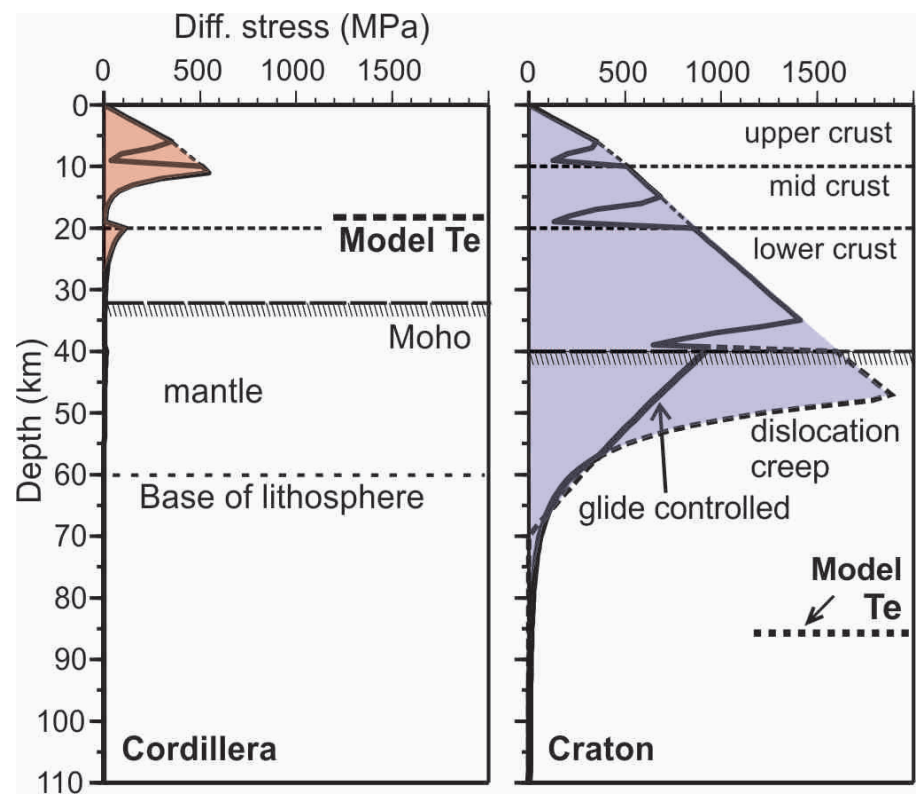

Figure 13. Strength versus depth estimates for the Cordilleran backarc compared to the craton (assuming in compession), based on temperature-depth estimates and laboratory rheology (modified from Hyndman et al. 2009). In the Cordillera there is significant strength only in the upper crust.

pressure, and deformation at greater depths follows power law creep (Karato and Wu 1993) at a common plate-boundary deformation rate of $\sim 10^{-15} \mathrm{~s}^{-1}$. In the example shown, the upper crust is taken to have the rheology of granite, the lower crust of diabase, and the mantle of olivine (e.g. Ranalli 1995). There is considerable uncertainty in the deformation mechanisms and how laboratory data should be applied, but using our estimated backarc temperatures, most models have significant tectonic strength only in the upper $15-20 \mathrm{~km}$ of the crust and little strength in the lower crust. The uppermost mantle is slightly stronger but still tectonically very weak. In contrast, for cold craton regions there is a strong crust and upper mantle to at least $60 \mathrm{~km}$. In all models, the much thinner and weaker lithosphere predicted for backarcs compared to cratons is clear. For large-scale deformation models we need the total strength of the lithosphere, which may be estimated by integrating the strength over depth (Fig. 14). In this figure, 'wet' and 'dry' refer to the laboratory rheologies that may apply to backarc mobile belts and cratons, respectively. The combined crustal- and mantle-lithosphere strength for backarc mobile belts is at least 10 times less and may be as much as 100 times less than that of cratons.

The above analysis indicates that the Cordilleran backarc is easily deformed. The mobile belt lithosphere strengths of $<$ $5 \times 10^{12} \mathrm{~N} / \mathrm{m}$ are within the range suggested for plate-tectonic forces and the elevation gravitational potential of mountain belts of $1-10 \times 10^{12} \mathrm{~N} / \mathrm{m}$ (e.g. Lynch and Morgan 1987; Whittakaer et al. 1992; Zoback et al. 2002). In contrast, cratonic lithospheres are too strong to be readily deformed. Some special process that weakens the cratonic lithosphere is required for deformation to occur, and these regions thus remain stable for long periods of geological time. Alternatively, if one fixes the plate-boundary forces at their estimated values, the calculated strain rates for backarcs are in the range observed for mobile belts like the Cordillera and are very small for stable 

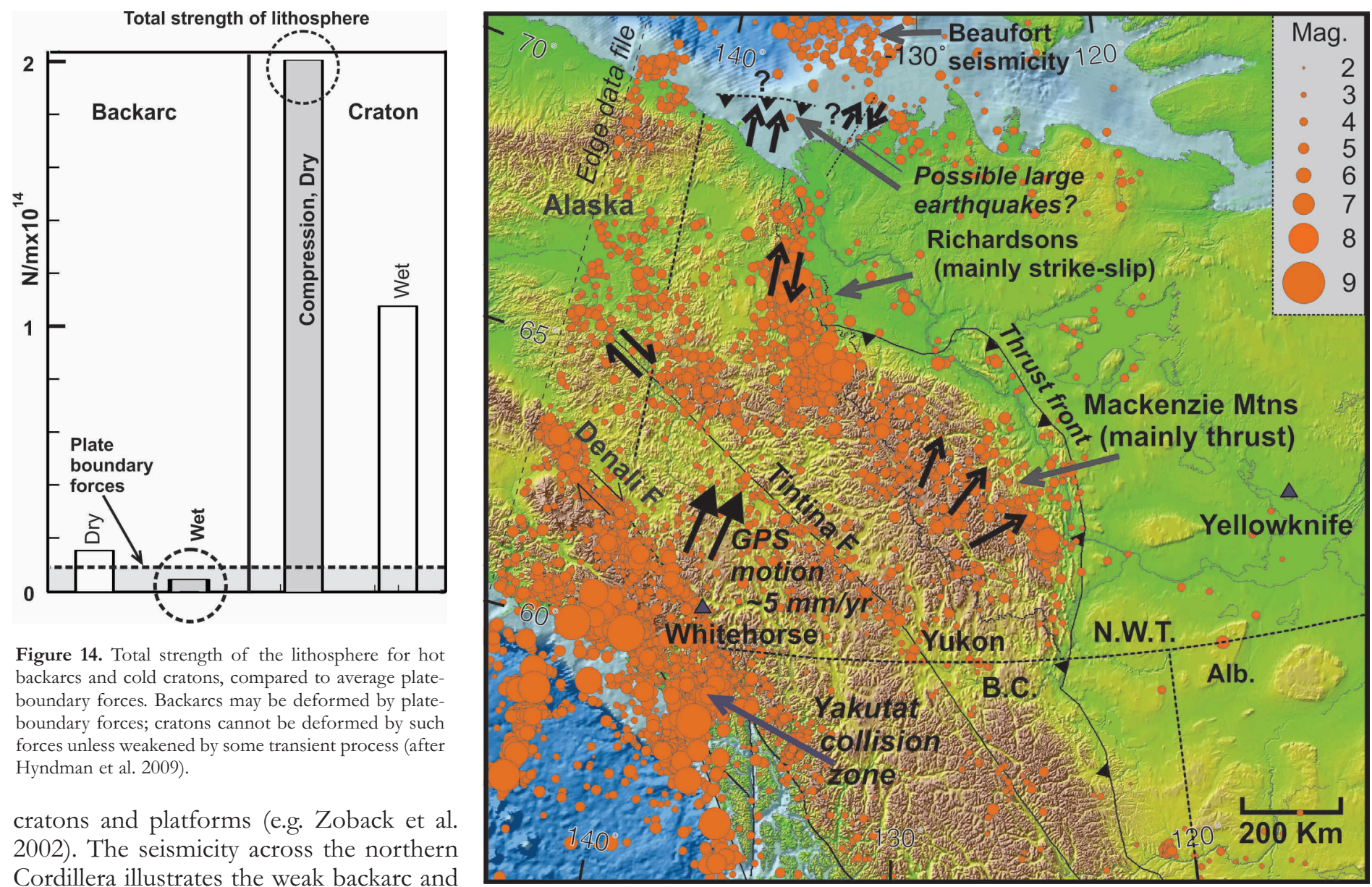

Figure 14. Total strength of the lithosphere for hot backarcs and cold cratons, compared to average plateboundary forces. Backarcs may be deformed by plateboundary forces; cratons cannot be deformed by such forces unless weakened by some transient process (after Hyndman et al. 2009).

cratons and platforms (e.g. Zoback et al. 2002). The seismicity across the northern Cordillera illustrates the weak backarc and the low seismicity in the adjacent strong craton (Fig. 15). This large difference in lithosphere strength between hot backarcs and cold cratons plays a major role in subsequent orogenic deformation.

\section{Collision Deformation}

In simple continental collision, one side of the suture will have been a subduction zone with a hot backarc, i.e. the hangingwall. The other side commonly will have been a cool rifted margin, i.e. the footwall. Therefore, we expect that there will be very little deformation on the cold footwall side which has strong lithosphere. Of course, in detail, the collision zone will be complex because the former arc and forearc, and possibly accreted oceanic terranes, will lie between these bounding blocks. The type example of continental collision is that of India into Asia. As expected, almost all of the deformation has been on the Asian side, which was the former hot and weak backarc for the Tethys ocean subduction, now represented by the Himalayas and Tibet. The cratonic Indian side has hardly deformed, because its lithosphere is cool and strong. Most deformation associated with continental or terrane collision occurs in areas that formed part of the hot and weak backarc prior to collision, as concluded by Clark and Royden (2000).

\section{Effective Elastic Thickness, Te}

Two other useful indicators of the strength versus depth profiles that are strongly temperature-dependent are the effective elastic thickness $(\mathrm{Te})$ and the maximum depth of earthquakes. $T e$ is the thickness of the crust and upper mantle that can

maintain elastic strain due to topographic and density variation loads. It may be calculated from the coherence between gravity and topography with horizontal wavelength (Fig. 16) (for the Cordillera and adjacent craton, e.g. Flück et al. 2003; Hyndman et al. 2009; for the adjacent craton, e.g. Audet and Mareschal 2007). The elastic thickness is 'effective' because it may be the combination of two or more layers, e.g. the upper crust and upper mantle with an intervening weak lower crust layer. There also is a dependence on the uncertain duration of the loads, but it provides a good first-order estimate of elastic thickness. Te in the Cordilleran backarc is less than $20 \mathrm{~km}$, in good agreement with model predictions based on crustal temperature and composition. There is negligible strength in the upper mantle. Te is greater than $60 \mathrm{~km}$ in the craton indicating considerable strength in the uppermost mantle.

\section{Maximum Depth of Earthquakes}

The maximum depth of earthquakes in the crust depends strongly on temperature. In the Cordilleran backarc most earthquakes are shallower than $15 \mathrm{~km}$, consistent with Te estimates. Hyndman et al. (2003) show an example for the Cascadia backarc where there is intense seismicity. The critical temperature depends somewhat on composition and strain rate, but is $350-450^{\circ} \mathrm{C}$ for common crustal compositions and mobile-belt strain rates. There are few areas with sufficient 


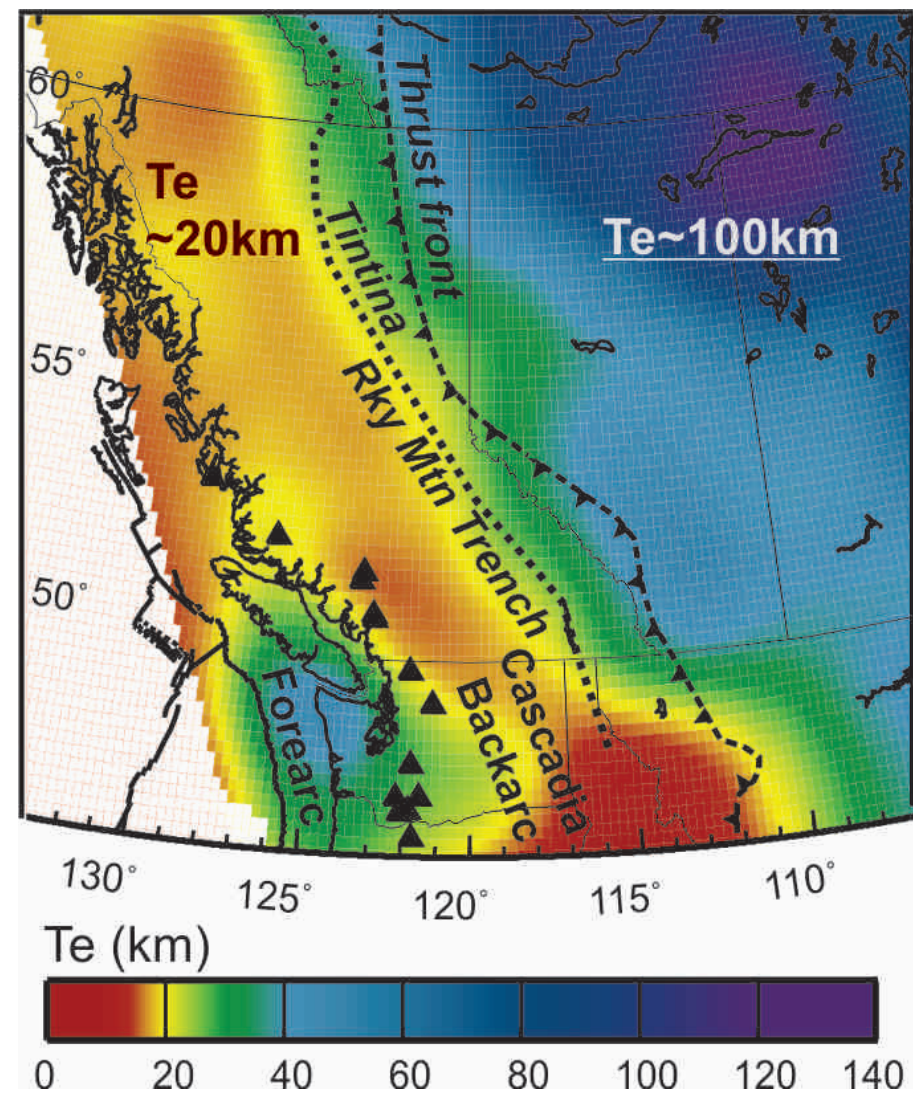

Figure 16. Effective elastic thickness $T e$, for the Cordillera and adjacent craton (after Flück et al. 2003). The average $T e$ is $15-20 \mathrm{~km}$ for the Cordillera and over 60 $\mathrm{km}$ for the craton.

earthquakes to define the depth range in the craton because the strain rates are so low, and there is a strain rate dependence of the maximum temperature for seismicity. However, an area in the Cascadia forearc has a similar cool crustal thermal regime and quite rapid deformation. In that area earthquakes extend to at least $25 \mathrm{~km}$ in the lower crust, corresponding again to $350-450^{\circ} \mathrm{C}$ (Hyndman et al. 2003).

\section{Flat Moho}

An interesting related observation is that the Moho is generally quite flat in backarcs, at a depth of about $33 \mathrm{~km}$ in the Cordillera, in spite of a wide range of deformation structures and differences in erosion levels (see Fig. 5). This can be understood by appreciating that the high temperatures mean very low strength in the lower crust and quite low strength in the uppermost mantle. Over long geological times, i.e. tens of millions of years, the Moho can be viewed as a 'liquid-liquid' boundary that relaxes to a near-horizontal gravitational equipotential through lateral flow of the lower crust and perhaps the uppermost mantle (see Bird 1991; McKenzie et al. 2000). Cook et al. (2010) provide seismic reflection sections and discuss such 'resetting' of the Moho, among other processes.

\section{Regional Backarc Volcanism}

There is a clear association of 'backarc' volcanism with the high-temperature Cordillera and other continental backarcs, in contrast to the rare volcanism in cratons. I will not discuss this association in any detail, but simply point out the relevant

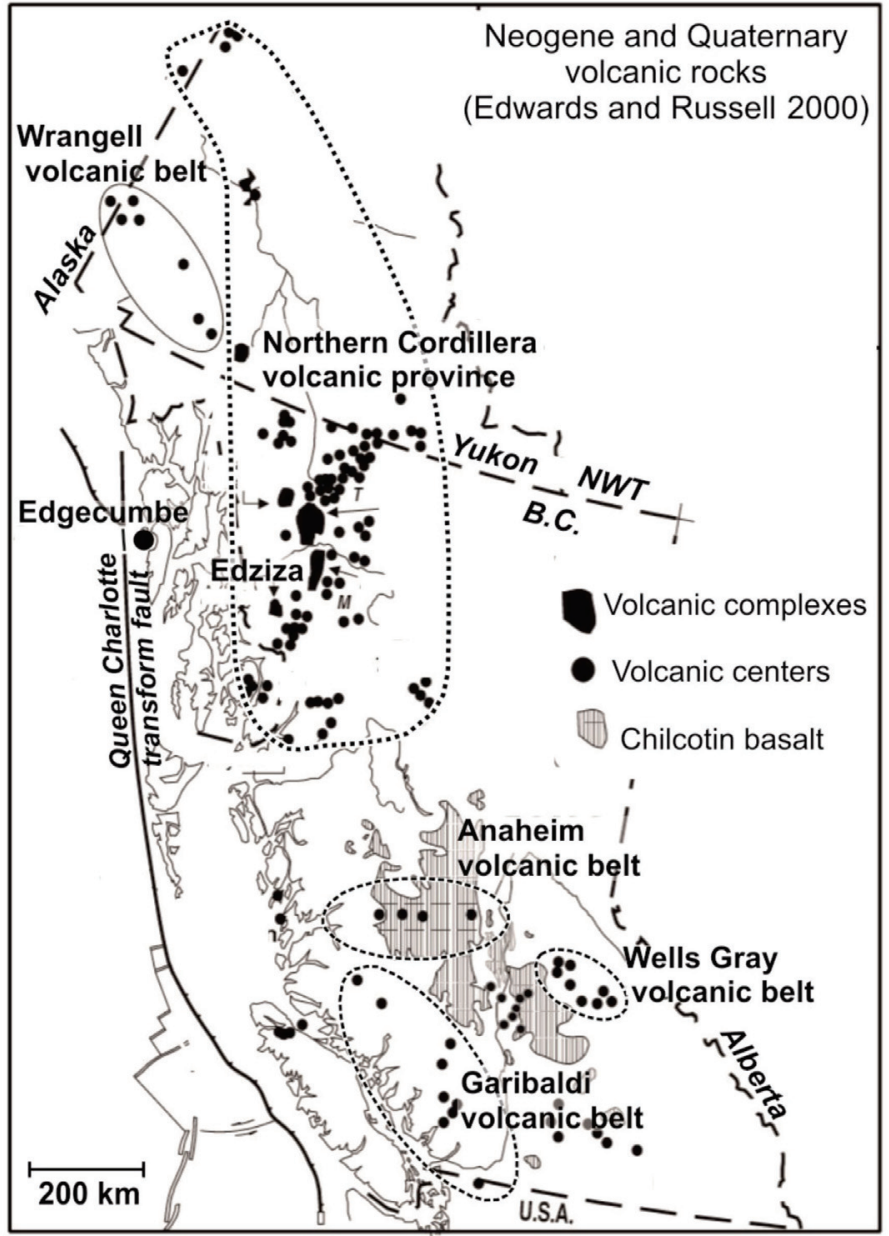

Figure 17. Distribution of the widespread Quaternary volcanic rocks that are restricted to the Cordilleran backarc (modified after Edwards and Russell 2000).

observations. Throughout most of the Cordillera there has been widespread sporadic Cenozoic volcanism as summarized by Armstrong and Ward (1991, and references therein) and Edwards and Russell (2000) (Fig. 17). The latter mapped the extent of magmatic fields between eastern Alaska and northern Mexico during the successive time intervals of 55-40, $40-25,25-10$, and $10-0 \mathrm{Ma}$. They found that some areally extensive and voluminous intermediate-composition magmatic fields coincide with extensional metamorphic core complexes that likely represent collapse of orogenically-thickened crust and high elevations. Widespread and frequent volcanism is not surprising, as temperatures are close to the upper-mantle solidus at shallow depths of $\sim 60 \mathrm{~km}$ in the Cordilleran backarc mantle, and melting may be fluxed by subduction water input. A small tectonic extensional stress change can result in decompression melting. An interesting example is the Llangorse/ Edziza volcanic field in northwest British Columbia (e.g. Souther et al. 1984; Armstrong and Ward 1991; Harder and Russell 2006), where the ongoing collision of the Yakutat Terrane in the corner of the Gulf of Alaska may be generating tensional tears in the adjacent lithosphere, facilitating late Cenozoic volcanism.

\section{Lower Crust Detachment and Regional Oroclines}

As I discussed earlier, the lower crust of the Cordillera and other continental backarcs must be very weak. Although it is 
also tectonically weak, the uppermost mantle in most estimates has greater strength than the overlying lower crust, so the two may move independently. We therefore expect that horizontal detachment may be common (e.g. Oldow et al. 1990), allowing decoupling of the lower crust and upper mantle. Remarkably, it appears that deformational forces can be transmitted over large distances solely through the strong upper crust of backarcs. The upper mantle may not be involved or may move independently. An example of lower-crust detachment and transport across the entire northern Cordillera was given by Mazzotti and Hyndman (2002). Much credit for establishing that lower-crust detachment is common goes to German geophysicist Rolf Meissner (e.g. Meissner and Mooney 1998; Meissner et al. 2006). He seems to have convinced most of the European geoscience community, but lower-crust detachment is less accepted and appreciated in North America.

As well as the arguments for low strength based on laboratory data and estimated lower-crust temperatures that I discussed earlier (Fig. 13), we now have several indicators that widespread detachment does occur in the Cordillera and other current or thermally recent backarcs. I discuss this evidence briefly below.

\section{Lower Crust Horizontal Reflectors}

In the Cordillera and a number of other current or recent backarcs there are common horizontal seismic reflector bands in the lower crust (e.g. Matthews 1986) that may be interpreted to result from horizontal detachment shearing (for the Cordillera, e.g. Clowes and Kanasewich 1970; Parsons et al. 1992). As summarized by Meissner et al. (2006), some of the clearest densely-laminated reflectivity in the lower crust is in Phanerozoic extensional areas that we now interpret to be in current or recent backarcs. There have been many discussions of possible causes of laminated reflectivity, including compositional layering, low-velocity fluid-filled shear zones, and horizontal magmatic intrusions (e.g. Wever and Meissner 1987; Hyndman and Shearer 1989; Warner 1990). What may be an important correlation is that the estimated temperature often is where many rocks become ductile $\left(350-450^{\circ} \mathrm{C}\right)$ at the top of the reflective layers and also at the top of the electrically-conductive layer in the lower crust of the Cordillera (Marquis et al. 1995). The conclusion of a tectonically very weak lower crust in backarcs supports the idea that lower-crust horizontal reflectivity is due to horizontal shearing.

In some areas, the horizontal seismic reflectivity extends up to the mid-crust (Fig. 18). Although the current temperatures at mid-crustal levels may be too low for ductile deformation, they may have been hotter when that level was deeper in a thickened crust in the past. Also, in a few areas the lower-crust reflectivity is $5-10 \mathrm{~km}$ above the base of the crust. In some hot backarcs, the lowermost crust is in granulite-facies conditions $\left(800-900^{\circ} \mathrm{C}\right.$ ) and so is anhydrous. This dry mineralogy may be stronger than the overlying slightly shallower and therefore cooler amphibolite-facies regions where there is more bound water that reduces the strength.

The reflectors are interpreted to result from stretching and flow of heterogeneities such as mafic intrusions, producing long thin sub-horizontal reflecting layers with marked contrasts in seismic impedance. Such layers could be 'frozen in' and remain as temperatures decline and the crust strengthens.

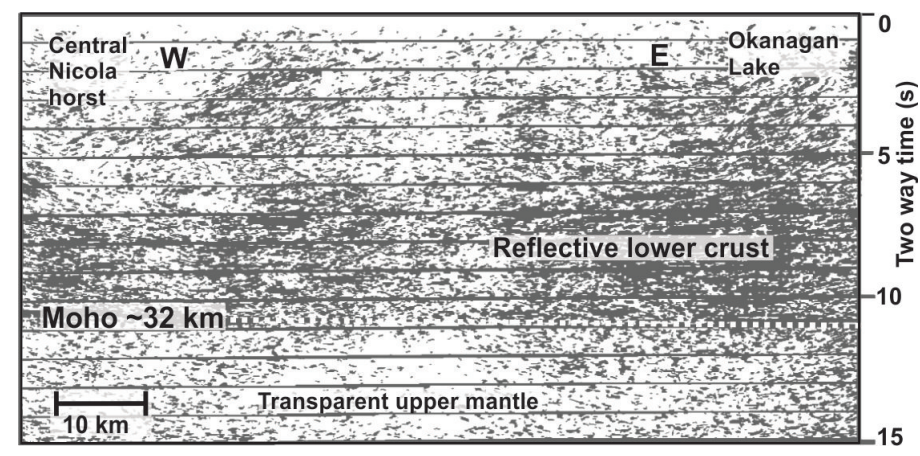

Figure 18. Seismic reflection section from the SE Canadian Cordillera Lithoprobe surveys showing pervasive lower-crust horizontal reflectors (after Cook et al. 1992).

Oueity and Clowes (2010) proposed such a development to explain seismic reflection and refraction characteristics at the base of the crust beneath the Paleoproterozic Great Bear magmatic arc in the Canadian Northwest Territories. However, lower-crust horizontal reflectors are less common in geologically older areas, so a variety of geological processes may reduce the layered impedance contrasts over long periods of time.

Important support for shearing as the origin of lowercrustal reflectors, is the observation of banding or lamination and anisotropy in amphibolite- to granulite-facies rocks formed in the lower crust, as inferred from petrological studies. In several large areas, exhumed lower-crustal rocks with strong horizontal compositional laminations are now exposed at the surface (e.g. Sandiford 1989; Dumond et al. 2010; Regan et al. 2014). Temperatures at the time of the lower-crust ductile flow were estimated to be about $800^{\circ} \mathrm{C}$ at $30 \mathrm{~km}$ depth.

In addition to these examples, there is the question of the role of lower-crust shearing in the formation of gneiss generally, especially banded gneisses (e.g. Myers 1978). The foliation of many, if not most, gneisses may result from horizontal shearing when they were in the lower crust. Where there are banded gneiss layers with strong impedance contrasts in the lower crust, they may be responsible for the observed horizontal seismic reflectivity.

\section{Tectonic Indicators of Lower Crust Detachment}

Lower-crust detachment is inferred from large-scale horizontal tectonic motions, especially the overthrusting of the upper crust of backarcs over the adjacent craton or stable platform as argued by Oldow et al. (1990). In a few places globally, where the backarc crust is especially thick, there may be extrusion of the very weak lower crust (e.g. Bird 1991; Royden et al. 1997; Beaumont et al. 2001), including under core complexes (Block and Royden 1990). Lower-crust extrusion has been discussed for an area of the SE Canadian Cordillera (e.g. Gervais and Brown 2011). In backarcs that have very thick crust, like the high Andes, it has been suggested that there may even be convection in the lower crust (e.g. Babeyko et al. 2002).

Several tectonic observations support horizontal shearing in the lower crust and horizontal transport of the upper crust in backarcs. Lower-crust detachments seem necessary to explain the common characteristics of foreland fold and thrust belts where the upper mobile belt crust is thrust over the stable craton or platform, apparently without the upper mantle moving, or moving independently. The lower-crustal detach- 

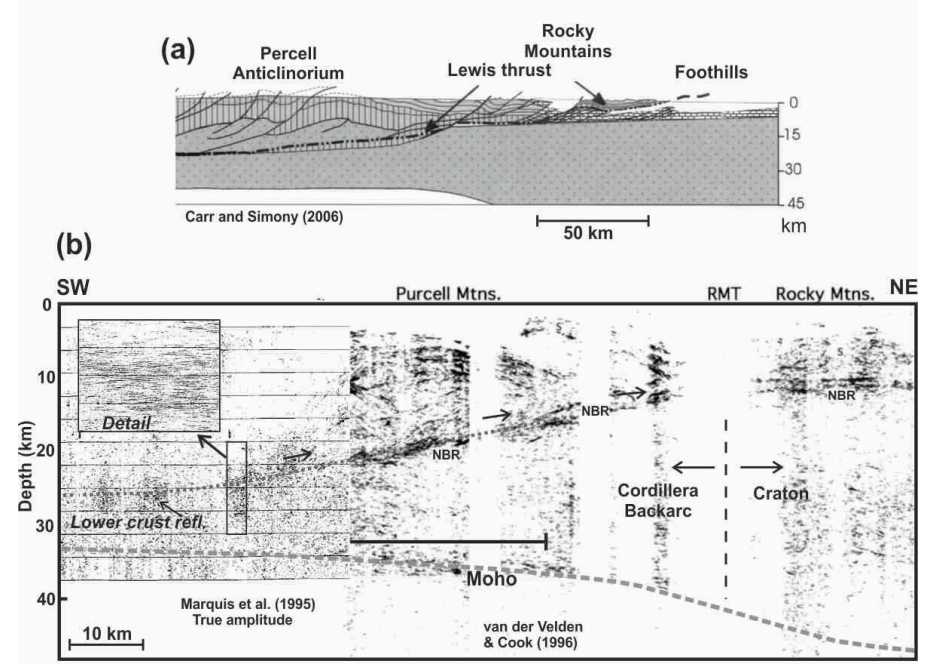

Figure 19. (a) Geological section across the Rocky Mountain Front (after Carr and Simony 2006) illustrating the thrusting of the backarc upper crust over the craton. (b) Seismic reflection section showing the lower-crust detachment in the Cordillera (after Marquis et al. 1995) rising to join the basal thrust (NBR) of the foreland sediment section (after van de Velden and Cook 1996).

ment in the backarc hinterland may connect to the basal detachment in foreland thrusting that is weakened by high fluid pressure (see seismic sections in Fig. 19). Examples are the current northern Canadian Cordillera (Mazzotti and Hyndman 2002), and Laramide-age structures in the southern Canadian Cordillera (e.g. Brown et al. 1992; van der Velden and Cook 1996; Hyndman and Lewis 1999; Carr and Simony 2006). The current Andes of central South America (Hindle et al. 2002) may be similar. As previously discussed, the Yakutat terrane collision in the corner of the Gulf of Alaska has been interpreted to be the cause of current seismically-active thrust deformation of the Mackenzie Mountains at the foreland belt $800 \mathrm{~km}$ to the east (Fig. 20), and for northerly crustal motion and thrusting in the Mackenzie River Delta (Mazzotti and Hyndman 2002; Leonard et al. 2008). The backarc lower-crust detachment must be sufficiently weak to transfer the stress from the plate-boundary collision and the gravitational potential of the elevation of the high coastal mountains to the weak foreland fold and thrust belt far to the east, even though only the upper Cordilleran crust has significant strength. In contractional orogens, it has been argued that a through-going basal detachment in the lower crust separates the entire crustal section from the underlying mantle lithosphere (e.g. Oldow et al. 1990; Mazzotti and Hyndman 2002) (Fig. 21). If this is correct for backarc mobile belts like the Cordillera, thrust faults, transcurrent faults, and extensional faulting commonly are restricted to the overlying detached crustal section.

\section{Oroclines}

Another geological process that may involve lower-crust detachment is the development of oroclines. The concept of large-scale crustal deformation in a horizontal plane with little vertical deformation was first described in detail by Warren Carey in Tasmania (Carey 1955). Johnston et al. (2013) provided a detailed review of this process that involves bending or buckling about a vertical axis of rotation. Several examples in backarcs are the Cordillera-Alaska orocline (e.g. Johnston

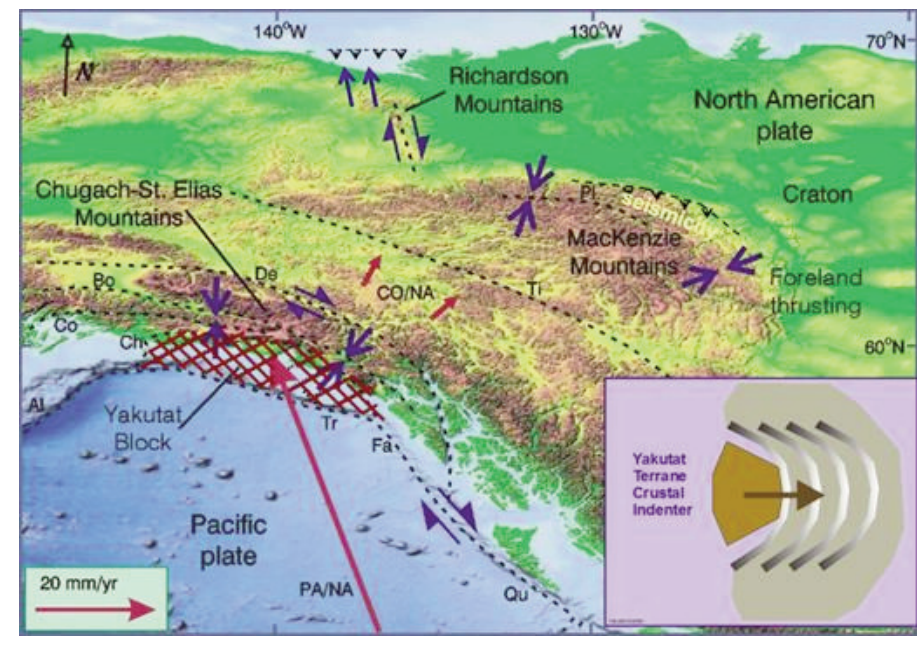

Figure 20. The Yakutat Terrane collision indenter in the Gulf of Alaska that drives the whole Cordilleran upper crust across the Cordillera to the active Mackenzie Mountains fold and thrust belt, and north to the fold and thrust belt of the Mackenzie River Delta (Mazzotti and Hyndman 2002; Leonard et al. 2008).

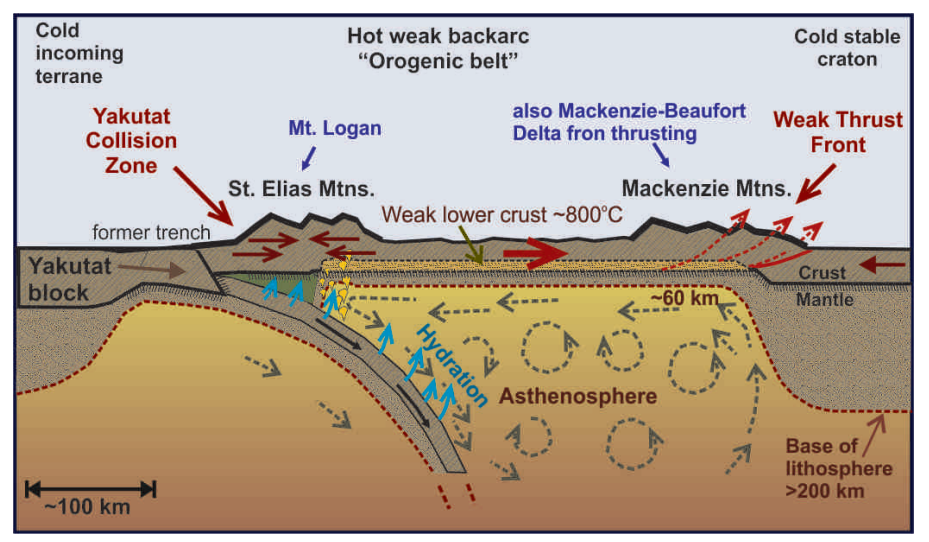

Figure 21. Model cross-section illustrating the current strain transfer across the northern Cordillera from the Yakutat collision zone to the Mackenzie Mountains that are overthrusting the craton (after Mazzotti and Hyndman 2002).

2001, 2008), and the Cantabrian of northern Spain (e.g. Weil et al. 2000). There is an important question in oroclinal bending that has not yet been well studied, i.e. what happens to the upper mantle? If the upper mantle is involved in the bending, we should expect substantial thickening and thinning of the lithosphere at bends that is not evident in topography or structure. If the upper mantle and lower crust have negligible tectonic strength, as suggested here, they can readily move out of the way as the upper crust bends, and the upper crust may move independently over the lower crust detachment. This model requires that there be translation of the upper crust over hundreds of kilometres.

Since we conclude that sufficiently high temperatures for lower-crust detachment mainly occur in hot subduction zone backarcs, the weak orogenic hinterland that hosts most largescale oroclines must also be in the backarcs. Cratons and other tectonically old lithospheres are too strong to deform in this way. A tentative conclusion is that most oroclines involve only the upper crust. The uppermost mantle may not move or may follow a different trajectory. The physical processes involved in oroclinal deformation, especially the depth of deformation, are topics that need further study. 


\section{Continental Collision, Orogenic Heat, and Bimodal Metamorphic Belts}

\section{Barrovian Metamorphism}

Another important recent conclusion that I will discuss only briefly is that the high temperatures estimated for backarcs like the Cordillera are consistent with the increasing evidence that regional 'Barrovian' metamorphism predates the deformation in orogenic belts. There is no "heat of orogeny." The most common style of regional metamorphism in time and space is the 'Barrovian' metamorphic series first defined by George Barrow (1893) who, in the late 19th century, mapped a series of zones of progressive metamorphism in a sequence exposed in the Scottish Highlands. Subsequent studies have shown peak metamorphic temperatures of $600-700^{\circ} \mathrm{C}$ at crustal depths of 20-30 km (e.g. Jamieson et al. 1998, and references therein). The temperature at the base of a $35 \mathrm{~km}$ thick crust like the Cordillera thus was about $800^{\circ} \mathrm{C}$, if there was a normal downward increasing gradient. This is very similar to the temperatures that we infer at the base of the crust in the Cordillera and other current backarcs.

High paleotemperatures are a defining feature of now deeply-exhumed orogenic belts, as inferred from widespread high-temperature regional metamorphism, granitic plutonism, and ductile deformation at mid- to lower-crustal depths. However, the origin of these regional high paleotemperatures has been difficult to understand. As Jamieson et al. (1998) state, a quantitative explanation for Barrovian metamorphism in thermal-tectonic models of orogenesis has proven elusive (e.g. Loosveld and Etheridge 1990; Jamieson et al. 1998; Thompson et al. 2001; Vanderhaeghe and Teyssier 2001; Collins 2002). Commonly the heat and high temperatures are simply ascribed to 'orogenic heating' without reference to the actual mechanism. In fact, most orogenic processes should absorb heat. Orogenic belts that involve underthrusting put cool near-surface material at greater depths, resulting in decreased temperature gradients. Alternatively, the crust may be tectonically thickened, which stretches the isotherms vertically, reducing the gradient. Significant frictional strain-heating is unlikely because, if the crust is strong enough for significant frictional heating, it is too strong to be deformed by available plateboundary and gravitational forces.

Two main sources of heat have been previously proposed. The first is the emplacement of upper crustal rocks with high radioactive heat-generation into the lower crust during the shortening (see Jamieson et al. 1998, 2007). In shortening and underthrusting models there is an evolving competition between cooling by the underthrusting and thickening, and radioactive heating within the deforming orogenic belt. Such underthrusting can produce the metamorphic temperatures (e.g. Jamieson et al. 1998). However, this explanation predicts maximum temperatures 50-100 m.y. after collision, whereas peak metamorphic assemblages are commonly argued to be earlier than, or at least synchronous with, the thickening (e.g. Thompson et al. 2001; Collins 2002). A good example where the high temperatures are concluded to originate some 100 m.y. prior to deformation is the Aracuai orogeny of Eastern Brazil (Gradim et al. 2014). The radioactive-heating model also does not explain how shortening and thickening can be initiated in cold, strong lithosphere prior to the heating. As I dis- cussed earlier, the available plate-boundary and gravitational forces are much too small to deform stable cold strong lithosphere. The second suggested heat source is backarc extension prior to collision. This explanation requires that such extension must occur less than about 50 m.y. before the collision orogeny in order for the heat not to have decayed. As well, Thompson et al. (2001) argue that there must be thinning of the mantle lithosphere with little thinning of the crust to explain the inferred crustal thicknesses following collision. A much more satisfactory model is that hot and thin backarc lithosphere is the primary locus of shortening (Hyndman et al. 2005), such that the high temperatures predate the deformation. This explanation corresponds to the vise or inheritedweakness model (e.g. Ellis et al. 1998; Thompson et al. 2001; Collins 2002).

We argue that the heat for the metamorphism comes from the pre-existing hot backarc, not from the orogenic deformation process itself. Figure 22 illustrates the correspondence between the Cordillera backarc thermal regime as in Figure 10, and the temperature-depth profile of Barrovian metamorphic gradients, i.e. $600-700^{\circ} \mathrm{C}$ at $20-30 \mathrm{~km}$ (see summary by Jamieson et al. 1998). Recognizing that most continental- or terrane-collision orogens inherit pre-existing hot and weak backarcs may resolve the long-standing problem of the origin of the high temperatures associated with orogeny. There is no actual "heat of orogeny." The high temperatures existed in the backarc of one side of the collisional orogen prior to the collision and the shortening deformation.

For the type case of Scotland Barrovian metamorphism, the situation is well stated by Johnson and Strachan (2006):

"Geochronological data indicate that the Caledonian thrust sheets of NW Scotland were assembled in less than $18 \mathrm{Ma}$, yet regional Barrovian metamorphism to amphibolite facies and local melting occurred syn-thrusting. ... it is clear that there is insufficient time to generate the high metamorphic temperatures during the thrusting event. ... a plausible explanation for the heat source is ... a 20-25 Ma period of crustal heating in a back-arc setting... Most of the orogenic heat therefore came from the pre-existing back-arc rather than the orogenic process itself."

\section{Orogenic Belt One-sided Deformation}

The high-temperature backarc thermal regime and inferred weak lithosphere model also provides insight into the shortening in continental collisions. As we should expect, the deformation occurs primarily on the side of the closing ocean that had the arc and the weak backarc. This one-sided deformation pattern is very clear for the India-Asia collision. Most of the deformation has been on the Asian side, which represents the former hot and weak backarc. The leading edge of the Himalayan Mountains appears to be backarc crust overthrusting the largely undeformed strong Indian lithosphere. Initial shortening and crustal thickening appear to be concentrated at the leading and trailing edges of the backarc mobile belt. In this example, shortening is mainly in the Himalayan mountain front and in several shortening zones to the north of Tibet. The Tibetan plateau has experienced little shortening, at least of its upper crust. Another example that I have worked on is the current collision of the Yakutat terrane in the Gulf of Alaska that started at about $6 \mathrm{Ma}$. Here, there has been strong 


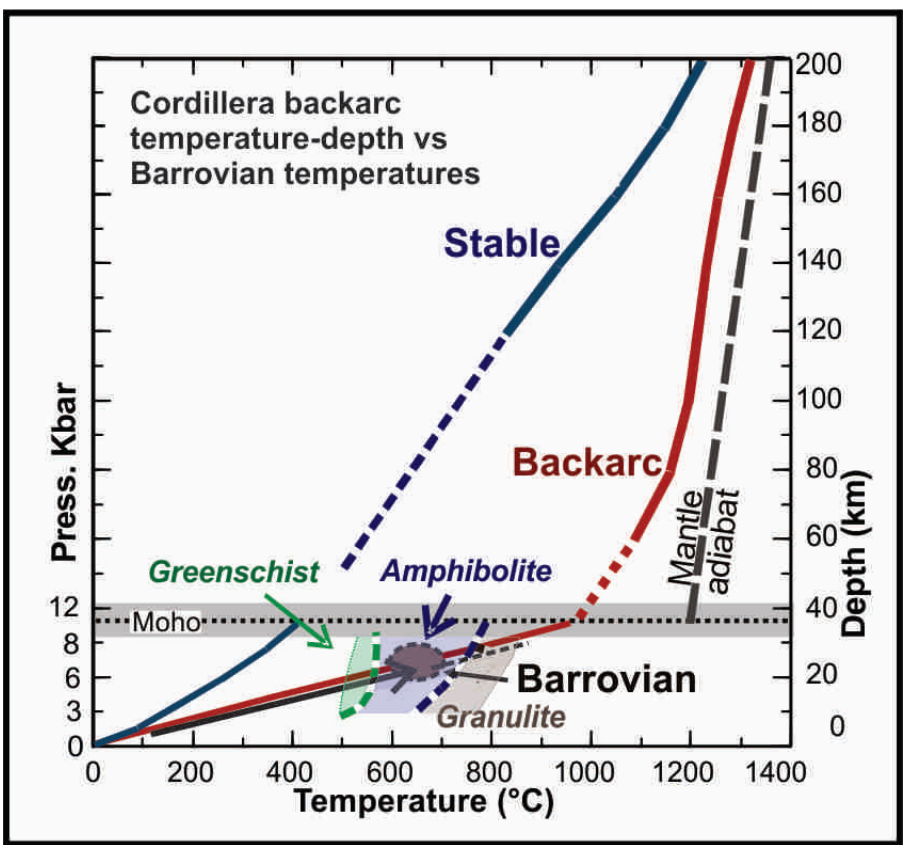

Figure 22. Barrovian metamorphic temperatures (e.g. $600-700^{\circ} \mathrm{C}$ at $20-30 \mathrm{~km}$; see Jamieson et al. 1998) compared to temperatures estimated for the Cordillera and other backarcs. The lower crust is in granulite-facies conditions.

shortening in the coastal collision zone that was a former backarc (St. Elias Mountains area) and again in foreland thrusting of the Mackenzie Mountains of the eastern Cordillera. There is little shortening in the intervening central Cordillera as evident by the pattern of current seismicity (Fig. 15), and the crust remains thin $(32-35 \mathrm{~km})$ (e.g. Mazzotti and Hyndman 2002). With further shortening, the high temperatures may allow the crust of the whole backarc to be thickened to $>50$ $\mathrm{km}$, such as for the Altiplano of the South American Andes, for Tibet, and perhaps for the Laramide orogeny of western North America, producing a broad high elevation plateau.

\section{Bimodal Metamorphism}

Another characteristic of ancient collisional orogenic belts is the presence of paired bimodal metamorphic belts, defined by contrasting high-pressure/low temperature and low-pressure/high-temperature conditions. As described by Brown (2010), "Paired metamorphic belts are belts of contrasting... thermal gradient, one warmer and the other colder, juxtaposed by plate tectonics process, formed during or shortly after the formation of the containing rock stratum." This metamorphic contrast may be explained by one side (the hanging-wall side) of a suture being the former hot arc-backarc hinterland and the other being the incoming little-deformed cold continental crust (the footwall side) (e.g. Brown 2006).

\section{CONCLUSIONS}

The conclusions of the work summarized in this article are based on the now strong evidence that the North American Cordillera and most other backarcs are remarkably uniformly hot with thin $(\sim 60 \mathrm{~km})$ lithospheres. They contrast with the cold Canadian Shield, and other cratons and stable platforms, (thermotectonic ages greater than $500 \mathrm{Ma}$ ) which have thick $(200-250 \mathrm{~km})$ lithospheres. The thermal structure of backarc regions has consequences for their elevations, mechanical strength and other physical properties, for regional metamorphism, and has important implications for the behaviour of the crust and mantle during collisional orogenesis.

We now have strong constraints on the temperatures in the crust and upper mantle. These include, (1) Heat flow and radioactive heat-generation data, (2) Temperature-sensitive upper-mantle seismic velocities, especially from shear-wave tomography, and (3) Kimberlite and volcanic xenoliths that constrain the temperature-depth profile in the upper mantle at the time of eruption. Several other constraints with lesser precision indicate similar thermal regimes, and support the conclusion of uniformly high temperatures in backarc regions in contrast to cold cratons and other stable areas.

Some of the numerous important consequences of the high Cordillera backarc temperatures are:

(1) The high elevation of the Cordillera is supported by thermal isostasy, in spite of the region having a thin crust.

(2) The Cordillera and other mountain belts are mainly in backarcs. These regions are mobile belts; they exhibit long-term weakness compared to adjacent cratons and stable platforms. They deform readily because they are hot and weak enough to be deformed by plate-boundary forces and gravitational forces linked to their high elevations. Most current seismicity is in weak backarcs. Backarcs may be hot because of shallow asthenosphere convection, facilitated by water driven upward from the underlying subducting plate.

(3) Most volcanism away from subduction zone volcanic arcs is located in backarcs like the Cordillera. Temperatures are close to the solidus at shallow depths in the mantle and partial melting may be fluxed by water being driven off the underlying subducting oceanic plate or by extensional stresses.

(4) Orogenic shortening during continental collision is concentrated in former backarc mobile belts that are much weaker than the adjacent stable areas. The pre-existing or inherited high temperatures of these regions provide an explanation for widespread orogenic plutonism, high-temperature regional metamorphism, and ductile crustal deformation.

(5) Backarc and subsequent orogenic belt temperatures are high enough to allow lower-crust detachment that decouples complex surface tectonics from the uppermost mantle. Such detachment allows the upper backarc crust to overthrust strong cratons in foreland belts. The detachment also may mean that most oroclines are detached in the lower crust and do not involve the mantle. In a few areas of hot and thick crust, lower-crustal flow and extrusion may occur.

(6) The "heat of orogeny" and Barrovian metamorphism may be a consequence of high backarc temperatures prior to collision, not a result of the collision process itself. Paired metamorphic belts may represent juxtaposition in a collision suture of a hot backarc against a cold craton or stable platform. 


\section{ACKNOWLEDGEMENTS}

I wish to thank the many graduate students, postdoctoral fellows, and colleagues that have collaborated with me on the various aspects of the work described in this article, and that have provided stimulating and challenging discussions. Claire Currie, Stephane Mazzotti, Lucinda Leonard, Paul Flück, and Guy Marquis are especially thanked. Reviewers Ron Clowes and Andrew Hynes made very helpful comments and recommendations that significantly improved the manuscript, and a third reviewer provided some thought-provoking discussion of the concepts involved.

\section{REFERENCES}

Adams, J., and Atkinson, G., 2003, Development of seismic hazard maps for the proposed 2005 edition of the National Building Code of Canada: Canadian Journal of Civil Engineering, v. 30, p. 255-271, http://dx.doi.org/10.1139/102070

Aitchison, J.C., Ali, J.R., and Davis, A.M., 2007, When and where did India and Asia collide?: Journal of Geophysical Research, v. 112, B05423, http://dx.doi.org/ 10.1029/2006JB004706.

Arcay, D., Doin, M.P., Tric, E., Bousquet, R., and De Capitani, C., 2006, Overriding plate thinning in subduction zones: Localized convection induced by slab dehydration: Geochemistry, Geophysics, Geosystems, v. 7, Q02007, http://dx.doi.org/10.1029/2005GC001061.

Argand, E., 1924, La tectonique de l'Asie: International Geological Congress Proceedings, v. 7, p. 171-372.

Armstrong, R.L., and Ward, P., 1991, Evolving geographic patterns of Cenozoic magmatism in the North American Cordillera: The temporal and spatial association of magmatism and metamorphic core complexes: Journal of Geophysical Research, v. 96, p. 13201-13224, http://dx.doi.org/10.1029/91JB00412.

Artemieva, I.M., and Mooney, W.D., 2001, Thermal thickness and evolution of Precambrian lithosphere: A global study: Journal of Geophysical Research, v. 106, p. 16387-16414, http://dx.doi.org/10.1029/2000JB900439.

Audet, P., and Mareschal, J-C., 2007, Wavelet analysis of the coherence between Bouguer gravity and topography: application to the elastic thickness anisotropy in the Canadian Shield: Geophysical Journal International, v. 168, p. 287-298, http://dx.doi.org/10.1111/j.1365-246X.2006.03231.x.

Babeyko, A.Y., Sobolev, S.V., Trumbull, R.B., Oncken, O., and Lavier, L.L., 2002, Numerical models of crustal scale convection and partial melting beneath the Altiplano-Puna plateau: Earth and Planetary Science Letters, v. 199, p. 373-388, http://dx.doi.org/10.1016/S0012-821X(02)00597-6.

Bao, X., Eaton, D.W., and Guest, B., 2014, Plateau uplift in western Canada caused by lithospheric delamination along a craton edge: Nature Geoscience, v. 7, p. 830-833, http://dx.doi.org/10.1038/ngeo2270.

Barrow, G., 1893, On an intrusion of muscovite-biotite gneiss in the southeastern Highlands of Scotland, and its accompanying metamorphism: Quaternary Journal of the Geological Society, v. 49, p. 330-358, http://dx.doi.org/10.1144/ GSL.JGS.1893.049.01-04.52.

Beaumont, C., Jamieson, R.A., Nguyen, M.H., and Lee, B., 2001, Himalayan tectonics explained by extrusion of a low-viscosity crustal channel coupled to focused surface denudation: Nature, v. 414, p. 738-742, http://dx.doi.org/10.1038/ 414738a.

Beck, M.E., Jr., 1988, Analysis of late Jurassic-recent paleomagnetic data from active plate margins of South America: Journal of South American Earth Science, v. 1, p. 39-52, http://dx.doi.org/10.1016/0895-9811(88)90014-4.

Becker, T.W., Faccenna, C., Humphreys, E.D., Lowry, A.R., and Miller, M.S., 2013, Static and dynamic support of western United States topography: Earth and Planetary Science Letters, v. 402, p. 234-246, http://dx.doi.org/10.1016/ j.epsl.2013.10.012.

Bilham, R., Larson, K., Freymueller, J., and Project Idylhim members, 1997, GPS measurements of present-day convergence across the Nepal Himalaya: Nature, v. 386, p. 61-64, http://dx.doi.org/10.1038/386061a0.

Bird, P., 1991, Lateral extrusion of lower crust from under high topography in the isostatic limit: Journal of Geophysical Research, v. 96, p. 10275-10286, http://dx.doi.org/10.1029/91JB00370.

Blackwell, D.D., Steele, J.L., Kelley, S., and Korosec, M.A., 1990, Heat flow in the state of Washington and thermal conditions in the Cascade Range: Journal of Geophysical Research, v. 95, p. 19495-19516, http://dx.doi.org/10.1029/ JB095iB12p19495

Block, L., and Royden, L.H., 1990, Core complex geometries and regional scale flow in the lower crust: Tectonics, v. 9, p. 557-567, http://dx.doi.org/10.1029/ TC009i004p00557.

Braun, J., 2010, The many surface expressions of mantle dynamics: Nature Geoscience, v. 3, p. 825-833, http://dx.doi.org/10.1038/ngeo1020.

Brown, M., 2006, Duality of thermal regimes is the distinctive characteristic of plate tectonics since the Neoarchean: Geology, v. 34, p. 961-964, http://dx.doi.org/ 10.1130/G22853A.1.

Brown, M., 2010, Paired metamorphic belts revisited: Gondwana Research, v. 18, p. 46-59, http://dx.doi.org/10.1016/j.gr.2009.11.004.
Brown, R.L., Carr, S.D., Johnson, B.J., Coleman, V.J., Cook, F.A., and Varsek, J.L., 1992, The Monashee décollement of the southern Canadian Cordillera: a crustal-scale shear zone linking the Rocky Mountain Foreland belt to lower crust beneath accreted terrane, in McClay, K.R., ed., Thrust tectonics: Springer Netherlands, p. 357-364.

Burianyk, M.J.A., Kanasewich, E.R., and Udey, N., 1997, Broadside wide-angle seismic studies and three-dimensional structure of the crust in the southeast Canadian Cordillera: Canadian Journal of Earth Sciences, v. 34, p. 1156-1166, http://dx.doi.org/10.1139/e17-093.

Canil, D., 2008, Canada's craton: A bottoms-up view: GSA Today, v. 18, p. 4-10, http://dx.doi.org/10.1130/GSAT01806A.1.

Carey, S.W., 1955, The orocline concept in geotectonics-Part I: Papers and Proceedings of the Royal Society of Tasmania, v. 89, p. 255-288.

Carr, S.D., and Simony, P.S., 2006, Ductile thrusting versus channel flow in the southeastern Canadian Cordillera: evolution of a coherent crystalline thrust sheet: Geological Society, London, Special Publications, v. 268, p. 561-587, http://dx.doi.org/10.1144/GSL.SP.2006.268.01.26.

Cassidy, J.F., 1995, Review: Receiver function studies in the southern Canadian Cordillera: Canadian Journal of Earth Sciences, v. 32, p. 1514-1519, http://dx.doi.org/10.1139/e95-123.

Chapman, D.S., and Pollack, H.N., 1975, Global heat flow: A new look: Earth and Planetary Science Letters, v. 28, p. 23-32, http://dx.doi.org/10.1016/0012$821 X(75) 90069-2$.

Chapman, D.S., and Pollack, H.N., 1977, Regional geotherms and lithospheric thickness: Geology, v. 5, p. 265-268, http://dx.doi.org/10.1130/0091-7613(1977)5 $<265$ :RGALT $>2.0$. CO;2.

Christensen, N.I., and Mooney, W.D., 1995, Seismic velocity structure and composition of the continental crust: A global view: Journal of Geophysical Research, v. 100, p. 9761-9788, http://dx.doi.org/10.1029/95JB00259.

Clark, M.K., and Royden, L.H., 2000, Topographic ooze: Building the eastern margin of Tibet by lower crustal flow: Geology, v. 28, p. 703-706, http://dx.doi.org/10.1130/0091-7613(2000)28<703:TOBTEM>2.0.CO;2.

Clowes, R.M., and Kanasewich, E.R., 1970, Seismic attenuation and the nature of reflecting horizons within the crust: Journal of Geophysical Research, v. 75, p. 6693-6705, http://dx.doi.org/10.1029/JB075i032p06693.

Clowes, R.M., Zelt, C.A., Amor, J.R., and Ellis, R.M., 1995, Lithospheric structure in the southern Canadian Cordillera from a network of seismic refraction lines: Canadian Journal of Earth Sciences, v. 32, p. 1485-1513, http://dx.doi.org/ $10.1139 / \mathrm{e} 95-122$.

Collins, W.J., 2002, Hot orogens, tectonic switching, and creation of continental crust: Geology, v. 30, p. 535-538, http://dx.doi.org/10.1130/00917613(2002)030<0535:HOTSAC>2.0.CO;2.

Cook, F.A., Varsek, J.L., Clowes, R.M., Kanasewich, E.R., Spencer, C.S., Parrish, R.R., Brown, R.L., Carr, S.D., Johnson, B.J., and Price, R.A., 1992, Lithoprobe crustal reflection cross section of the southern Canadian Cordillera, 1, Foreland thrust and fold belt to Fraser River Fault: Tectonics, v. 11, p. 12-35, http://dx.doi.org/10.1029/91TC02332.

Cook, F.A., White, D.J., Jones, A.G., Eaton, D.W.S., Hall, J., and Clowes, R.M., 2010, How the crust meets the mantle: Lithoprobe perspectives on the Mohorovičić discontinuity and crust-mantle transition: Canadian Journal of Earth Sciences, v. 47, p. 315-351, http://dx.doi.org/10.1139/E09-076

Currie, C.A., and Hyndman, R.D., 2006, The thermal structure of subduction zone back arcs: Journal of Geophysical Research, v. 111, B08404, http://dx.doi.org/ 10.1029/2005JB004024.

Currie, C.A., Wang, K., Hyndman, R.D., and He, J., 2004, The thermal effects of steady-state slab-driven mantle flow above a subducting plate: The Cascadia subduction zone and backarc: Earth and Planetary Science Letters, v. 223, p. 35-48, http://dx.doi.org/10.1016/j.epsl.2004.04.020.

Dewey, J.F., and Bird, J.M., 1970, Mountain belts and the new global tectonics: Journal of Geophysical Research, v. 75, p. 2625-2647, http://dx.doi.org/10.1029/ JB075i014p02625.

Dixon, J.E., Dixon, T.H., Bell, D.R., and Malservisi, R., 2004, Lateral variation in upper mantle viscosity: Role of water: Earth and Planetary Science Letters, v. 222, p. 451-467, http://dx.doi.org/10.1016/j.epsl.2004.03.022.

Dumond, G., Goncalves, P., Williams, M.L., and Jercinovic, M.J., 2010, Subhorizontal fabric in exhumed continental lower crust and implications for lower crustal flow: Athabasca granulite terrane, western Canadian Shield: Tectonics, v. 29, TC2006, http://dx.doi.org/10.1029/2009TC002514.

Eaton, D.W., Darbyshire, F., Evans, R.L., Grütter, H., Jones, A.G., and Yuan, X., 2009, The elusive lithosphere-asthenosphere boundary (LAB) beneath cratons: Lithos, v. 109, p. 1-22, http://dx.doi.org/10.1016/j.lithos.2008.05.009.

Edwards, B.R., and Russell, J.K., 2000, Distribution, nature, and origin of Neogene-Quaternary magmatism in the northern Cordilleran volcanic province, Canada: Geological Society of America Bulletin, v. 112, p. 1280-1295, http://dx.doi.org/10.1130/0016-7606(2000)112<1280:DNAOON>2.0.CO;2.

Ellis, S., Beaumont, C., Jamieson, R.A., and Quinlan, G., 1998, Continental collision 
including a weak zone: the vise model and its application to the Newfoundland Appalachians: Canadian Journal of Earth Sciences, v. 35, p. 1323-1346, http://dx.doi.org/10.1139/e97-100

Engebretson, D.C., Cox, A., and Gordon, R.G., 1985, Relative motions between oceanic and continental plates in the Pacific basin: Geological Society of America Special Papers, v. 206, p. 1-60, http://dx.doi.org/10.1130/SPE206-p1.

Feldl, N., and Bilham, R., 2006, Great Himalayan earthquakes and the Tibetan plateau: Nature, v. 444, p. 165-170, http://dx.doi.org/10.1038/nature05199.

Flament, N., Gurnis, M., and Müller, R.D., 2013, A review of observations and models of dynamic topography: Lithosphere, v. 5, p. 189-210, http://dx.doi.org/ 10.1130/L245.1.

Flück, P., Hyndman, R.D., and Lowe, C., 2003, Effective elastic thickness $T_{e}$ of the lithosphere in western Canada: Journal of Geophysical Research, v. 108, 2430, http://dx.doi.org/10.1029/2002JB002201

Frankel, A.D., Mueller, C.S., Barnhard, T.P., Leyendecker, E.V., Wesson, R.L., Harmsen, S.C., Klein, F.W., Perkins, D.M., Dickman, N.C., Hanson, S.L., and Hopper, M.G., 2000, USGS national seismic hazard maps: Earthquake spectra, v. 16, p. 1-19, http://dx.doi.org/10.1193/1.1586079.

Gervais, F., and Brown, R.L., 2011, Testing modes of exhumation in collisional orogens: Synconvergent channel flow in the southeastern Canadian Cordillera: Lithosphere, v. 3, p. 55-75, http://dx.doi.org/10.1130/L98.1.

Gough, D.I., 1986, Mantle upflow tectonics in the Canadian Cordillera: Journal of Geophysical Research, v. 91, p. 1909-1919, http://dx.doi.org/10.1029/ JB091iB02p01909.

Gradim, C., Roncato, J., Pedrosa-Soares, A.C., Cordani, U., Dussin, I., Alkmim, F.F., Queiroga, G., Jacobsohn, T., da Silva, L.C., and Babinski, M., 2014, The hot back-arc zone of the Araçuaí orogen, Eastern Brazil: from sedimentation to granite generation: Brazilian Journal of Geology, v. 44, p. 155-180, http://dx.doi.org/10.5327/Z2317-4889201400010012.

Greenfield, A.M.R., Ghent, E.D., and Russell, J.K., 2013, Geothermobarometry of spinel peridotites from southern British Columbia: implications for the thermal conditions in the upper mantle: Canadian Journal of Earth Sciences, v. 50, p 1019-1032, http://dx.doi.org/10.1139/cjes-2013-0037.

Griffin, W.L., O’Reilly, S.Y., Doyle, B.J., Pearson, N.J., Coopersmith, H., Kivi, K., Malkovets, V., and Pokhilenko, N., 2004, Lithosphere mapping beneath the North American plate: Lithos, v. 77, p. 873-922, http://dx.doi.org/10.1016/ j.lithos.2004.03.034.

Gutscher, M-A., Spakman, W., Bijwaard, H., and Engdahl, E.R., 2000, Geodynamics of flat subduction: Seismicity and tomographic constraints from the Andean margin: Tectonics, v. 19, p. 814-833, http://dx.doi.org/10.1029/ 1999 TC001152.

Harder, M., and Russell, J.K., 2006, Thermal state of the upper mantle beneath the Northern Cordilleran Volcanic Province (NCVP), British Columbia, Canada: Lithos, v. 87, p. 1-22, http://dx.doi.org/10.1016/j.lithos.2005.05.002.

Hasebe, K., Fujii, N., and Uyeda, S., 1970, Thermal processes under island arcs: Tectonophysics, v. 10, p. 335-355, http://dx.doi.org/10.1016/0040 1951(70)90114-9.

Hasterok, D., and Chapman, D.S., 2007, Continental thermal isostasy: 2. Application to North America: Journal of Geophysical Research, v. 112, B06415, http://dx.doi.org/0.1029/2006JB004664.

Hindle, D., Kley, J., Klosko, E., Stein, S., Dixon, T., and Norabuena, E., 2002, Consistency of geologic and geodetic displacements during Andean orogenesis: Geophysical Research Letters, v. 29, p. 29-1-29-4, http://dx.doi.org/10.1029/ 2001 GL013757.

Hyndman, R.D., 2010, The consequences of Canadian Cordillera thermal regime in recent tectonics and elevation: a review: Canadian Journal of Earth Sciences, v 47, p. 621-632, http://dx.doi.org/10.1139/E10-016.

Hyndman, R.D., and Currie, C.A., 2011, Why is the North America Cordillera high? Hot backarcs, thermal isostasy, and mountain belts: Geology, v. 39, p. 783-786, http://dx.doi.org/10.1130/G31998.1.

Hyndman, R.D., and Hamilton, T.S., 1993, Queen Charlotte area Cenozoic tectonics and volcanism and their association with relative plate motions along the northeastern Pacific margin: Journal of Geophysical Research, v. 98, p. 14257-14277, http://dx.doi.org/10.1029/93JB00777.

Hyndman, R.D., and Lewis, T.J., 1995, Review: The thermal regime along the southern Canadian Cordillera Lithoprobe corridor: Canadian Journal of Earth Sciences, v. 32, p. 1611-1617, http://dx.doi.org/10.1139/e95-129.

Hyndman, R.D., and Lewis, T.J., 1999, Geophysical consequences of the Cordilleracraton thermal transition in southwestern Canada: Tectonophysics, v. 306, p $397-422$.

Hyndman, R.D., and Shearer, P.M., 1989, Water in the lower continental crust: modelling magnetotelluric and seismic reflection results: Geophysical Journal International, v. 98, p. 343-365

Hyndman, R.D., Mazzotti, S., Weichert, D., and Rogers, G.C., 2003, Frequency of large crustal earthquakes in Puget Sound-Southern Georgia Strait predicted from geodetic and geological deformation rates: Journal of Geophysical
Research, v. 108, 2033, http://dx.doi.org/10.1029/2001JB001710.

Hyndman, R.D., Currie, C.A., and Mazzotti, S.P., 2005, Subduction zone backarcs, mobile belts, and orogenic heat: GSA Today, v. 15, p. 4-10, http://dx.doi.org/ 10.1130/1052-5173(2005)15<4:SZBMBA>2.0.CO;2.

Hyndman, R.D., Currie, C.A., Mazzotti, S., and Fredricksen, A., 2009, Temperature control of continental lithosphere thickness, Te vs $V_{s}$ : Earth and Planetary Science Letters, v. 277, p. 539-548, http://dx.doi.org/10.1016/j.epsl.2008.11.023.

Irving, E., 1954, The palaeomagnetism of the Torridonian sandstone series of North-Western Scotland: Unpublished PhD thesis, University of Cambridge, Cambridge, UK

Jamieson, R.A., Beaumont, C., Fullsack, P., and Lee, B., 1998, Barrovian regional metamorphism: Where's the heat?: Geological Society, London, Special Publications, v. 138, p. 23-51, http://dx.doi.org/10.1144/GSL.SP.1996.138.01.03.

Jamieson, R.A., Beaumont, C. Nguyen, M.H., and Culshaw, N.G., 2007, Synconvergent ductile flow in variable strength continental crust: Numerical models with application to the western Grenville orogen: Tectonics, v. 26, TC5005, http://dx.doi.org/10.1029/2006TC002036.

Johnson, M.R.W., and Strachan, R.A., 2006, A discussion of possible heat sources during nappe stacking: the origin of Barrovian metamorphism within the Caledonian thrust sheets of NW Scotland: Journal of the Geological Society, v. 163, p. 579-582, http://dx.doi.org/10.1144/0016-764920-168.

Johnston, S.T., 2001, The Great Alaskan Terrane Wreck: reconciliation of paleomagnetic and geological data in the northern Cordillera: Earth and Planetary Science Letters, v. 193, p. 259-272, http://dx.doi.org/10.1016/S0012 $821 \mathrm{X}(01) 00516-7$

Johnston, S.T., 2008, The Cordilleran ribbon continent of North America: Annual Review of Earth and Planetary Sciences, v. 36, p. 495-530, http://dx.doi.org/ 10.1146/annurev.earth.36.031207.124331.

Johnston, S.T., Weil, A.B., and Gutiérrez-Alonso, G., 2013, Oroclines: Thick and thin: Geological Society of America Bulletin, v. 125, p. 643-663, http://dx.doi.org/10.1130/B30765.1.

Kao, H., Behr, Y., Currie, C.A., Hyndman, R., Townend, J., Lin, F-C., Ritzwoller, M.H., Shan, S-J., and He, J., 2013, Ambient seismic noise tomography of Canada and adjacent regions: Part I, Crustal structures: Journal of Geophysical Research, Solid Earth, v. 118, p. 5865-5887, http://dx.doi.org/10.1002/ 2013JB010535.

Karato, S-i., and Wu, P., 1993, Rheology of the upper mantle: a synthesis: Science, v. 260, p. 771-778, http://dx.doi.org/10.1126/science.260.5109.771.

Khazaradze, G., and Klotz, J., 2003, Short and long term effects of GPS measured crustal deformation rates along the south central Andes: Journal of Geophysical Research, v. 108, 2289, http://dx.doi.org/10.1029/2002JB001879.

Kind, R., Yuan, X., Saul, J., Nelson, D., Sobolev, S.V., Mechie, J., Zhao, W., Kosarev, G., Ni, J., Achauer, U., and Jiang, M., 2002, Seismic images of crust and upper mantle beneath Tibet: Evidence for Eurasian plate subduction: Science, v. 298, p. 1219-1221, http://dx.doi.org/10.1126/science.1078115.

Kukačka, M., and Matyska, C., 2008, Numerical model of heat flow in back-arc regions: Earth and Planetary Science Letters, v. 276, p. 243-252, http://dx.doi.org/10.1016/j.epsl.2008.07.055

Lachenbruch, A.H., and Morgan, P., 1990, Continental extension, magmatism and elevation; formal relations and rules of thumb: Tectonophysics, v. 174, p. 39-62, http://dx.doi.org/10.1016/0040-1951(90)90383-J.

Lachenbruch, A.H., and Sass, J.H., 1978, Models of an extending lithosphere and heat flow in the Basin and Range province, in Smith, R.B., and Eaton, G.P., eds., Cenozoic Tectonics and Regional Geophysics of the Western Cordillera: Geological Society of America Memoirs, v. 152, p. 209-250, http://dx.doi.org/ 10.1130/MEM152-p209.

Leonard, L.J., Mazzotti, S., and Hyndman, R.D., 2008, Deformation rates estimated from earthquakes in the northern Cordillera of Canada and eastern Alaska: Journal of Geophysical Research, v. 113, B08406, http://dx.doi.org/10.1029/ 2007 JB005456.

Levandowski, W., Jones, C.H., Shen, W., Ritzwoller, M.H., and Schulte-Pelkum, V., 2014, Origins of topography in the western U.S.: Mapping crustal and upper mantle density variations using a uniform seismic velocity model: Journal of Geophysical Research, v. 119, p. 2375-2396, http://dx.doi.org/10.1002/ 2013 JB010607.

Lewis, T.J., Bentkowski, W.H., and Hyndman, R.D., 1992, Crustal temperatures near the Lithoprobe southern Canadian Cordillera transect: Canadian Journal of Earth Sciences, v. 29, p. 1197-1214, http://dx.doi.org/10.1139/e92-096.

Lewis, T.J., Hyndman, R.D., and Flück, P., 2003, Heat flow, heat generation, and crustal temperatures in the northern Canadian Cordillera: Thermal control of tectonics: Journal of Geophysical Research: Solid Earth, v. 108, 2316, http://dx.doi.org/10.1029/2002JB002090.

Loosveld, R.J.H., and Etheridge, M.A., 1990, A model for low pressure facies metamorphism during crustal thickening: Journal of Metamorphic Geology, v. 8, p. 257-267, http://dx.doi.org/10.1111/j.1525-1314.1990.tb00472.x.

Lynch, H.D., and Morgan, P., 1987, The tensile strength of the lithosphere and the 
localization of extension, in Coward, M.P., Dewey, J.F., and Hancock, P.L., eds, Continental Extensional Tectonics: Geological Society, London, Special Publications, v. 28, p. 53-65, http://dx.doi.org/10.1144/GSL.SP.1987.028.01.05.

MacKenzie, J.M., and Canil, D., 1999, Composition and thermal evolution of cratonic mantle beneath the central Archean Slave Province, NWT, Canada: Contributions to Mineralogy and Petrology, v. 134, p. 313-324, http://dx.doi.org/ $10.1007 / \mathrm{s} 004100050487$.

Majorowicz, J., Chan, J., Crowell, J., Gosnold, W., Heaman, L.M., Kück, J., Nieuwenhuis, G., Schmitt, D.R., Unsworth, M., Walsh, N., and Weides, S., 2014, The first deep heat flow determination in crystalline basement rocks beneath the Western Canadian Sedimentary Basin: Geophysical Journal International, v. 197, p. 731-747, http://dx.doi.org/10.1093/gii/ggu065.

Mareschal, J-C., and Jaupart, C., 2004, Variations of surface heat flow and lithospheric thermal structure beneath the North American craton: Earth and Planetary Science Letters, v. 223, p. 65-77, http://dx.doi.org/10.1016/ j.epsl.2004.04.002.

Marquis, G., Jones, A.G., and Hyndman, R.D., 1995, Coincident conductive and reflective middle and lower crust in southern British Columbia: Geophysical Journal International, v. 120, p. 111-131, http://dx.doi.org/10.1111/j.1365246X.1995.tb05915.x.

Matthews, D.H., 1986, Seismic reflections from the lower crust around Britain, in Dawson, J.B., Carswell, D.A., Hall, J., and Wedepohl, K.H., eds., The Nature of the Lower Continental Crust: Geological Society, London, Special Publications, v. 24, p. 11-21, http://dx.doi.org/10.1144/GSL.SP.1986.024.01.03.

Mazzotti, S., and Hyndman, R.D., 2002, Yakutat collision and strain transfer across the northern Canadian Cordillera: Geology, v. 30, p. 495-498, http://dx.doi.org/10.1130/0091-7613(2002)030<0495:YCASTA > 2.0.CO;2.

McCrory, P.A., and Wilson, D.S., 2013, A kinematic model for the formation of the Siletz-Crescent terrane by capture of coherent fragments of the Farallon and Resurrection plates: Tectonics, v. 32, p. 718-726, http://dx.doi.org/10.1002/ tect.20045

McGlashan, N., Brown, L., and Kay, S., 2008, Crustal thickness in the central Andes from teleseismically recorded depth phase precursors: Geophysical Journal International, v. 175 , p. 1013-1022, http://dx.doi.org/10.1111/j.1365246X.2008.03897.x.

McKenzie, D., Nimmo, F., Jackson, J.A., Gans, P.B., and Miller, E.L., 2000, Characteristics and consequences of flow in the lower crust: Journal of Geophysical Research, v. 105, p. 11029-11046, http://dx.doi.org/10.1029/1999JB900446.

Meissner, R., and Mooney, W., 1998, Weakness of the lower continental crust: a condition for delamination, uplift, and escape: Tectonophysics, v. 296, p. 47-60, http://dx.doi.org/10.1016/S0040-1951(98)00136-X.

Meissner, R., Rabbel, W., and Kern, H., 2006, Seismic lamination and anisotropy of the Lower Continental Crust: Tectonophysics, v. 416, p. 81-99, http://dx.doi.org/10.1016/j.tecto.2005.11.013.

Mooney, W.D., Laske, G., and Masters, T.G., 1998, CRUST 5.1: A global crustal model at $5^{\circ} \times 5^{\circ}$ : Journal of Geophysical Research, v. 103, p. 727-747, http://dx.doi.org/10.1029/97JB02122.

Myers, J.S., 1978, Formation of banded gneiss by deformation of igneous rocks: Precambrian Research, v. 6, p. 43-64, http://dx.doi.org/10.1016/03019268(78)90054-2.

Nyblade, A.A., and Pollack, H.N., 1993, A global analysis of heat flow from Precambrian terrains: Implications for the thermal structure of Archean and Proterozoic lithosphere: Journal of Geophysical Research, v. 98, p. 12207-12218, http://dx.doi.org/10.1029/93JB00521.

Oldow, J.S., Bally, A.W., and Avé Lallemant, H.G., 1990, Transpression, orogenic float, and lithospheric balance: Geology, v. 18, p. 991-994, http://dx.doi.org/ 10.1130/0091-7613(1990)018<0991:TOFALB > 2.3.CO;2.

Oueity, J., and Clowes, R.M., 2010, Nature of the Moho transition in NW Canada from combined near-vertical and wide-angle seismic reflection studies: Lithosphere, v. 2, p. 377-396, http://dx.doi.org/10.1130/L103.1.

Parsons, T., Howie, J.M., and Thompson, G.A., 1992, Seismic constraints on the nature of lower crustal reflectors beneath the extending Southern Transition Zone of the Colorado Plateau, Arizona: Journal of Geophysical Research, v. 97, p. 12391-12407, http://dx.doi.org/10.1029/92JB00947.

Pavlenkova, N.I., 1996, Crust and upper mantle structure in northern Eurasia from seismic data: Advances in Geophysics, v. 37, p. 1-133, http://dx.doi.org/ 10.1016/S0065-2687(08)60269-1.

Pollack, H.N., Hurter, S.J., and Johnson, J.R., 1993, Heat flow from the Earth's interior: Analysis of the global data set: Reviews of Geophysics, v. 31, p. 267-280, http://dx.doi.org/10.1029/93RG01249.

Ramos, V.A., 2010, The tectonic regime along the Andes: Present-day and Mesozoic regimes: Geological Journal, v. 45, p. 2-25, http://dx.doi.org/10.1002/gj.1193.

Ranalli, G., 1995, Rheology of the Earth: Springer, New York, 413 p.

Regan, S.P., Williams, M.L., Leslie, S., Mahan, K.H., Jercinovic, M.J., and Holland, M.E., 2014, The Cora Lake shear zone, Athabasca granulite terrane, an intraplate response to far-field orogenic processes during the amalgamation of
Laurentia: Canadian Journal of Earth Sciences, v. 51, p. 877-901, http://dx.doi.org/10.1139/cjes-2014-0015.

Rippe, D., Unsworth, M.J., and Currie, C.A., 2013, Magnetotelluric constraints on the fluid content in the upper mantle beneath the southern Canadian Cordillera: Implications for rheology: Journal of Geophysical Research, v. 118, p. 5601-5624, http://dx.doi.org/10.1002/igrb.50255

Ross, J.V., 1983, The nature and rheology of the Cordilleran upper mantle of British Columbia: Inferences from peridotite xenoliths: Tectonophysics, v. 100, p. 321-357, http://dx.doi.org/10.1016/0040-1951(83)90193-2.

Royden, L., and Keen, C.E., 1980, Rifting process and thermal evolution of the continental margin of eastern Canada determined from subsidence curves: Earth and Planetary Science Letters, v. 51, p. 343-361, http://dx.doi.org/ 10.1016/0012-821X(80)90216-2.

Royden, L.H., Burchfiel, B.C., King, R.W., Wang, E., Chen, Z., Shen, F., and Liu, Y., 1997, Surface deformation and lower crustal flow in eastern Tibet: Science, v. 276, p. 788-790, http://dx.doi.org/10.1126/science.276.5313.788.

Sandiford, M., 1989, Horizontal structures in granulite terrains: A record of mountain building or mountain collapse?: Geology, v. 17, p. 449-452, http://dx.doi.org/10.1130/0091-7613(1989)017<0449:HSIGTA>2.3.CO;2.

Saruwatari, K., Ji, S., Long, C., and Salisbury, M.H., 2001, Seismic anisotropy of mantle xenoliths and constraints on upper mantle structure beneath the southern Canadian Cordillera: Tectonophysics, v. 339, p. 403-426, http://dx.doi.org/10.1016/S0040-1951(01)00136-6.

Sleep, N.H., 2005, Evolution of the continental lithosphere: Annual Review of Earth and Planetary Sciences, v. 33, p. 369-393, http://dx.doi.org/10.1146/ annurev.earth.33.092203.122643.

Souther, J.G., Armstrong, R.L., and Harakal, J., 1984, Chronology of the peralkaline, late Cenozoic Mount Edziza volcanic complex, northern British Columbia, Canada: Geological Society of America Bulletin, v. 95, p. 337-349, http://dx.doi.org/10.1130/0016-7606(1984)95<337:COTPLC>2.0.CO;2.

Stockmal, G.S., and Beaumont, C., 1987, Geodynamic models of convergent margin tectonics: The southern Canadian Cordillera and the Swiss Alps: Canadian Society of Petroleum Geology Special Publications, Memoir 12, p. 393-411.

Tesauro, M., Kaban, M.K., and Cloetingh, S.A.P.L., 2008, EuCRUST-07: A new reference model for the European crust: Geophysical Research Letters, v. 35, L05313, http://dx.doi.org/10.1029/2007GL032244.

Thompson, A.B., Schulmann, K., Jezek, J., and Tolar, V., 2001, Thermally softened continental extensional zones (arcs and rifts) as precursors to thickened orogenic belts: Tectonophysics, v. 332, p. 115-141, http://dx.doi.org/10.1016/ S0040-1951(00)00252-3.

Townend, J., and Zoback, M.D., 2000, How faulting keeps the crust strong: Geology, v. 28, p. 399-402, http://dx.doi.org/10.1130/0091-7613(2000)28 $<399$ :HFKTCS $>2.0$. CO;2.

van der Velden, A.J., and Cook, F.A., 1996, Structure and tectonic development of the southern Rocky Mountain trench: Tectonics, v. 15, p. 517-544, http://dx.doi.org/10.1029/95TC03288.

Vanderhaeghe, O., and Teyssier, C., 2001, Partial melting and flow of orogens: Tectonophysics, v. 342, p. 451-472, http://dx.doi.org/10.1016/S00401951(01)00175-5.

Warner, M., 1990, Basalts, water, or shear zones in the lower continental crust? Tectonophysics, v. 173 , p. 163-174, http://dx.doi.org/10.1016/00401951(90)90214-S.

Watanabe, T., Langseth, M.G., and Anderson, R.N., 1977, Heat Flow in Back Arc Basins of the Western Pacific, in Talwani, M., and Pitman, W.C., eds., Island Arcs, Deep Sea Trenches and Back-Arc Basins: American Geophysical Union, Washington, D.C., p. 137-161, http://dx.doi.org/10.1029/ME001p0137.

Weil, A.B., Van der Voo, R., van der Pluijm, B.A., and Parés, J.M., 2000, The formation of an orocline by multiphased deformation: a paleomagnetic investigation of the Cantabria-Asturias Arc Hinge-Zone (northern Spain): Journal of Structural Geology, v. 22, p. 735-756, http://dx.doi.org/10.1016/S01918141(99)00188-1.

Wever, T., and Meissner, R., 1987, About the nature of reflections from the lower crust: Annales Geophysicae, Series B, v. 5, p. 349-352.

Whittakaer, A., Bott, M.H.P., and Waghorn, G.D., 1992, Stresses and plate boundary forces associated with subduction: Journal of Geophysical Research, v. 97, p. 11933-11944, http://dx.doi.org/10.1029/91JB00148.

Zhang, P-Z., Shen, Z., Wang, M., Gan, W., Bürgmann, R., Molnar, P., Wang, Q., Niu, Z., Sun, J., Wu, J., Hanrong, S., and Xinzhao, Y., 2004, Continuous deformation of the Tibetan Plateau from global positioning system data: Geology, v. 32, p. 809-812, http://dx.doi.org/10.1130/G20554.1.

Zoback, M.D., Townend, J., and Grollimund, B., 2002, Steady-state failure equilibrium and deformation of intraplate lithosphere: International Geology Review, v. 44, p. 383-401, http://dx.doi.org/10.2747/0020-6814.44.5.383.

Received April 2015

Accepted as revised August 2015 